\title{
CLITIC DOUBLING IN VERNACULAR MEDIEVAL GREEK ${ }^{1}$
}

\author{
By Jorie Soltic \\ University of Ghent
}

\begin{abstract}
This paper provides the first in-depth study of clitic doubling in vernacular Medieval Greek. First, it is shown that the four-part typology (topicalization; right-dislocation; backgrounding; left-dislocation) recently developed on the basis of Modern Greek is perfectly applicable to vernacular Medieval Greek. Moreover, clitic doubling serves the same pragmatic function in Medieval Greek as in many modern spoken languages: it marks an object as the topic of the utterance (as opposed to the focus). For this purpose, the notion of 'topic' is clearly defined and distinguished from the concept of (referential) 'givenness'. Special attention is paid to the distribution of the clitic pronouns, as their position is diagnostic for the topic/focus distinction. Innovatively, the frequent occurrence of clitic doubling in my corpus is associated with the oral discourse which the vernacular texts are acknowledged to adopt. In this regard, two other constructions are discussed: dislocated genitives and dislocated subjects.
\end{abstract}

\section{INTRODUCTION}

Clitic doubling is probably one of the most intensively studied issues in Modern Greek linguistics. While it has been noted that some instances of modern clitic doubling are already found in the vernacular language of the Greek Middle Ages (12-16th c.), a detailed analysis of the phenomenon in this period has not yet been undertaken.

In this paper, I show that clitic doubling serves the same pragmatic function in vernacular Medieval Greek as in Modern Greek, namely marking topics, as opposed to foci (in the sense of Gundel \& Fretheim 2004). Moreover, the typology which has recently been developed by Janse (2008) on the basis of Modern Greek is also applicable to vernacular Medieval Greek. However, a difference with the contemporary language is constituted by the fact that in Medieval Greek the construction is considered particularly typical of colloquial and thus spoken language. As such, the very frequent occurrence of clitic doubling in my corpus (three substantial romances) provides further evidence for the oral discourse which the vernacular Medieval Greek texts are acknowledged to adopt. In this regard, I also discuss two other constructions related to clitic doubling (dislocated genitives and dislocated subjects), as they typically occur in spoken language as well.

The paper is organized as follows: the first section deals with a general definition of clitic doubling. As the construction is usually called a 'topic marker', the notion 'topic' is clarified in the second section. In the third section, the scope is limited to Modern Greek. The fourth section deals with Medieval Greek clitic doubling: I provide evidence that the modern function of topic marker can be adopted. Furthermore, various examples are given which all

\footnotetext{
${ }^{1}$ My work was funded by the Research Foundation of Flanders (FWO) (grant no. B/13006/01).
} 
fit into the modern four-part typology of Janse (2008). The fifth section innovatively associates clitic doubling with the oral discourse employed in the vernacular texts. In the last section, my conclusions are formulated.

\section{Definition}

In modern linguistics, clitic doubling is defined as 'the co-occurrence of a direct and/or indirect object $\mathrm{NP}^{2}$ and a co-referential clitic pronoun attached to the verb' (Janse 2008: 165). Especially in Balkan languages, clitic doubling is a common phenomenon ${ }^{3}$ (Krapova \& Cinque 2008: 278), as in the example from Albanian in (1):

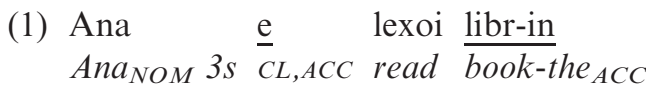

(Kallulli 2008: 230) ${ }^{4}$

'Ana read the book.'

Many answers have been proposed to the question when exactly this construction is used: the object should be animate/definite/familiar/specific/etc. (Guentchéva 2008: 203). However, most suggestions can be indirectly related to the current standard view: clitic doubling serves a pragmatic function in information structure; it is used as a device to mark the objects as topics, for instance: 'In Bulgarian, CD [clitic doubling] depends on the speaker's discourse strategies and correlates with topicalization of the object argument' (Guentchéva 2008: 204).

\section{The Topic AS A CONCEPT}

As is the case for many linguistic issues, much terminological confusion exists with regard to the notion 'topic(ality)'. Strictly speaking, the topic is the counterpart of the concept 'focus'. The topic/focus distinction captures the essence of the pair theme/rheme introduced by the Prague school (Guentchéva 2008: 211). Unfortunately, the concept 'topic' has often been equated with 'old', 'given' or 'known' information. Recently, Gundel \& Fretheim (2004) have clearly pointed out this double use of the term 'topic' (and to a lesser extent of the term 'focus'). They distinguish two types of 'givenness/newness': referential givenness/newness and relational givenness/newness. The proper use of the term 'topic' must be sought at the latter level, as the term 'can only apply to linguistic expressions' and 'involves a partition of the semantic/conceptual representation of a sentence into two complementary parts, $\mathrm{X}$ and $\mathrm{Y}$, where $\mathrm{X}$ is what the sentence is about [= topic, JS] (...) and $\mathrm{Y}$ is what is predicated about X [= focus, JS]' (Gundel \& Fretheim 2004: 176f.).

Referential givenness/newness, on the other hand, 'involves a relation between a linguistic expression and a corresponding non-linguistic entity in the speaker/hearer's mind, the discourse (model), or some real or possible world' (Gundel \& Fretheim 2004: 176). It is important to note that referential givenness/newness is gradual rather than binary: 'we need a richer taxonomy than the simple "given/new" distinction' (Brown \& Yule 1983: 182; see

\footnotetext{
2 As an NP can also be based on a pronoun, (strong) object pronouns too can be subject to clitic doubling. From a cross-linguistic perspective, however, this definition presents a rather restricted view. In standard Italian, for instance, prepositional phrases too can be subject to clitic doubling; in Italian dialects, even subjects can be accompanied by a coreferential clitic pronoun (Cinque 1990). My data too seem to suggest that this definition is incomplete: I have found one example of a doubled prepositional phrase (cf. fn. 13) and possessive pronouns can also be doubled (cf. section 6.3.1).

${ }^{3}$ However, in many Romance varieties as well, clitic doubling occurs, for example, Spanish: Ferraresi \& Lühr (2010).

${ }^{4}$ From now on, both the clitic pronoun and the doubled object are underlined.
} 
Geluykens 1992: 12), since referents may be more or less new with respect to each other. Examples of referential givenness/newness continua are Chafe's (1994) 'activation statuses', Gundel, Hedberg \& Zacharski’s (1993) 'givenness hierarchy' and Geluykens's (1992) 'recoverability scale'.

Since referential givenness/newness and relational givenness/newness are logically independent (Gundel \& Fretheim 2004: 179), it is possible that a referentially old piece of information is presented as the relationally most important information and thus as the focus of the utterance: 'it may well be the case that a focused constituent is given in the discourse' (Féry, Fanselow \& Krifka 2006: 7; see Féry 2006: 4), for instance:

(2) - Who called?

(Gundel \& Fretheim 2004: 179)

- Pat said she called

While 'she' is referentially given, it constitutes the relationally most important information and consequently functions as the focus of the utterance (topic $=$ 'called').

Nonetheless, a correlation seems to exist between the two types of givenness/newness, since it is natural that referentially new information coincides with the relationally most prominent and thus the focalized information. On the other hand, we expect referentially given information to constitute the topic of an utterance: 'there is, however, a good deal of empirical evidence for an independent connection between topic and some degree of referential givenness. Virtually the whole range of possible referential givenness conditions on topics has been suggested, including presupposition, familiarity, specificity, referentiality, and focus of attention' (Gundel \& Fretheim 2004: 179: 1.2. 'Referential properties of topic'). As such, it should no longer come as a surprise that the notion topic has often been conflated with referential givenness. In practice, the concept of referential givenness can actually be quite a good, i.e. objective, means to identify the topic. Whereas relational givenness/newness is a rather subjective affair, for the speaker decides what he presents as the most salient (Dik 1997: 326), ${ }^{5}$ with regard to referential givenness/newness, 'the speaker has no choice in the matter' (Gundel \& Fretheim 2004: 178; see Geluykens 1992: 12).

\section{Modern Greek}

\subsection{Topic marker}

This ambiguous use of the notion 'topic' is also found in definitions of clitic doubling in Modern Greek, in which the construction is also acknowledged to function as a topicality device: 'It is well-established that clitic-doubled DP-objects acquire a topicality reading and resist focalization' (Revithiadou \& Spyropulos 2008: 44), ${ }^{6}$ for example:

(3) $\frac{\text { tin }}{C L}, A C C$ loves $_{\text {lo }} \frac{\text { ti }}{A R T_{A C C}} \frac{\text { Yarimía }}{\text { Yarimía }_{A C C} 3 s}$

(Janse 2008: 167)

Topic: 'He loves Yarimía'

Versus

\footnotetext{
5 See Prince's Hearer-Old information: 'an entity is Hearer Old if the speaker believes the hearer to be already familiar with it' (Seidl \& Dimitriadis 1997: 377; footnote). Hearer Old can thus be equated with relational givenness or our topic. Prince also distinguishes Discourse-Old information, which is 'previously mentioned in the discourse'. This notion parallels our concept of referential givenness.

${ }^{6}$ See Philippaki-Warburton (1975; 1985); Haberland \& Van der Auwera (1987); Holten et al. (2004: 230ff.).
} 
(4) ti Yarimía ayapái

(Janse 2008: 171)

Focus: 'It is Yarímia he loves'

As just mentioned above, however, the topic reading is often mingled with the concept of referential givenness: 'Referentiality is the prerequisite for clitic doubling licensing' (Anagnostopoulou 1999: 761) and, less explicitly, 'the doubling of the in-situ direct object is, however, not free; only familiar, i.e. contextually bound direct, familiar direct objects are clitic-doubled' (Tomic 2006: 320).

Modern Greek, however, provides clear evidence that topicality is responsible for clitic doubling and that referential givenness is only an indirect, albeit natural, consequence of it. The mark of referential givenness is generally said to be definiteness: 'It has often been observed that, in English, new information is characteristically introduced by indefinite expressions and subsequently referred to by definite expressions (...). We find two predominant forms of expression used to refer to an entity treated as given, pronominals and definite NPs' (Brown \& Yule 1983: 169ff.). As a consequence, the fact that doubled objects are sometimes not accompanied by the definite article in Modern Greek point to the fact that it is not definiteness and thus not referential givenness that constitutes the prerequisite for licensing clitic doubling, but topicality. ${ }^{7}$ We can conclude that in Modern Greek, both definite and indefinite direct objects can be clitic-doubled if non-focused' (Tomic 2006: 323; cf. Philippaki-Warburton 1985; Iatridou 1995; Alexopoulou \& Folli 2011). In section 5.5, I show that the same applies to vernacular Medieval Greek.

\subsection{Typology}

Recently, Janse (2008: 167f.) has developed a clear typology of clitic doubling on the basis of Modern Greek. He distinguishes two criteria: presence or absence of a boundary pause (\#), and word order, more precisely: the position of the object $(\mathrm{O})$ vis-à-vis the verb $(\mathrm{V})$. This results in four different types of clitic doubling:

1. topicalization (OV; - boundary pause)

ti Yarimía tin a yapái $=\mathrm{O}$ clitic pronoun $\mathrm{V}$

2. topic left-dislocation (OV; + boundary pause)

ti Yarimía \# tin a yapái $=\mathrm{O}$ clitic pronoun $\mathrm{V}$

3. backgrounding (VO; - boundary pause)

tin a yapái ti Yarimía $=$ clitic pronoun $\mathrm{V} \mathrm{O}$

4. topic right-dislocation ( $\mathrm{VO}$; + boundary pause)

$\underline{\text { tin }}$ a yapái \# ti $\underline{\text { Yarimía }}=$ clitic pronoun $\mathrm{V} \mathrm{O}$

\footnotetext{
${ }^{7}$ However, the question whether so-called bare indefinites can be doubled in Modern Greek, has not been answered unanimously. Generally, the doubling of NPs lacking an indefinite article is considered ungrammatical, possibly with the exception of mass nouns, for instance:

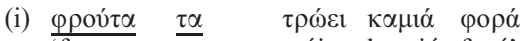

'frouta trói kamiá forá

$\overline{\text { fruit }_{A C C}} \overline{C L}, A C C$ eats from time to time

'Fruit, he eats from time to time.'

It has also been suggested that the grammaticality of doubled bare NPs actually depends on the specific type of clitic doubling: with topicalization and topic left- or right-dislocation, bare NPs might be possible, whereas backgrounding resists them (cf. section 4.2).
} 
It should be noted that these, albeit quite transparent, terms are not the standard ones. To begin with, 'clitic doubling' is usually not understood in this general sense, but commonly refers to what Janse calls 'backgrounding'. Janse's 'clitic left dislocation' and 'clitic right dislocation' are respectively called 'hanging topic left dislocation' and 'clitic right dislocation', while Janse's 'topicalization' is known as 'clitic left dislocation' in the syntactic literature (Cinque 1990; Anagnostopoulou 1994; Krapova \& Cinque 2008). To further complicate the matter the term 'topicalization' is reserved for dislocated phrases that are topics, but linked to a gap rather than a pronoun (Dimitriadis 1994; Alexopoulou \& Kolliakou 2002).

Furthermore, I am aware of the fact that the four categories present more subtle differences than is suggested here and that there are other, more fine-grained morphosyntactic criteria one may use in order to differentiate between them. It has been pointed out, for instance, that a lack of agreement between the NP and the clitic pronoun is normally not allowed in backgrounding constructions, while it is possible in topic right-dislocations. Thus, the four structures show in depth more dissimilarities than those acknowledged by Janse. Moreover, we should perhaps also recognize distinct properties according to the syntactic role of the doubled NP: direct objects and indirect objects seem to behave in a distinct way in the four constructions (see Cinque 1990; Krapova \& Cinque 2008 for discussion).

Thus, I realize that the picture is much more complicated than presented here. Nevertheless, with regard to my aim, providing a first description and initial categorization of the phenomenon in Medieval Greek without becoming too theoretical, I consider the two (surface) criteria proposed by Janse (2008) sufficient. Moreover, as I am dealing with a so-called 'dead' language, it would make no sense to lay down criteria which cannot be tested in my corpus. For instance, the employment of a criterion such as presence/absence of pitch accent would be highly irrelevant. Thus, although I admit that Janse's typology may be too simplified for a categorization of clitic doubling in spoken living languages, I consider it ideal with regard to my corpus.

In section 5.4, I demonstrate that this four-part typology is indeed perfectly applicable to vernacular Medieval Greek. However, before moving to examples of each type, the application of a typology making use of a prosodic criterion, namely, the presence/absence of a boundary pause, to purely written texts needs to be justified. First, however, it is necessary to discuss my corpus.

\section{Medieval Greek}

\subsection{Corpus}

The appearance of texts written in a vernacular idiom is in Medieval Greek inextricably connected with the use of the politikos stichos or fifteen-syllable metre. Thus, if one attempts to thoroughly examine the vernacular of the Greek Middle Ages (12-16th century), one is forced to include politikos stichos texts: it is 'the usual practice for compiling the corpus for this period, as the poetic vernacular texts are the most numerous' (Chila-Markopoulou 2004: 201). Despite their so-called 'poetic' character, however, the language of these texts feels quite natural, for the politikos stichos is a very flexible metre with a fluent, iambic rhythm: " "politischen Versen" (...) einem Versmaß, welches der natürlichen Aussprache und dem natürlichen Rhythmus der Volkssprache gut angepasst ist' 'the politikos stichos (...) a metre, which is well adapted to the natural pronunciation and the natural rhythm of the vernacular' (Rosenqvist 2007: 113). Given its enormous popularity and its predominance over prose, the

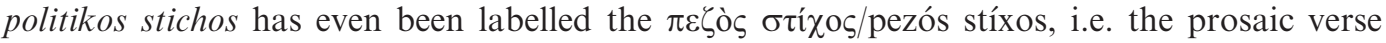
(Hinterberger 1993: 165). 
My corpus consists of three substantial texts composed in the politikos stichos: Libistros \& Rodamne (LR), Belthandros \& Chrysandza (BC) and Achilleis Byzantina (AB). These three texts present a quite coherent whole: all date from the fourteenth century, the heyday of the Medieval Greek vernacular, and all can be labelled (original Greek) 'romances', the genre par excellence during the Middle Ages (Beaton 1996). Importantly, the three romances, which total about 7,300 politikoi stichoi, ${ }^{8}$ also constitute a manageable corpus, i.e. large enough to be subject to statistical tests, but small enough to grasp the nuances of the texts, which constitutes a prerequisite for an analysis in terms of topic/focus.

\subsection{Boundary pauses in politikos stichos texts}

As mentioned above, the politikos stichos does not impose many metrical constraints. Beside the iambic pattern and the fixed number of fifteen syllables, a standard break (\#) is required after the eighth syllable (Lauxtermann 1999), for instance:

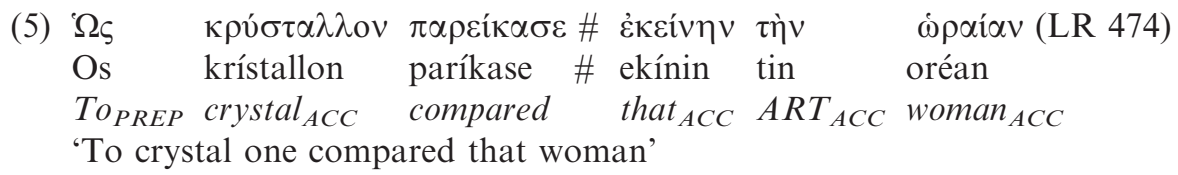

Note that only the even syllables $(2,6,10,14$ in this example) can carry a lexical accent (hence 'iambic' pattern).

Since the vernacular texts were presumably orally performed, this so-called caesura can be equated with a true boundary pause (cf. section 6). First, elision is avoided between the eighth and the ninth syllable, i.e. between the two parts divided by the caesura, as in the above example (Apostolopoulos 1984: 211). Second, the length of each part (of respectively 8 and 7 syllables) does not exclude a boundary pause: 'Wenn wir von einem menschlichen Atemvolumen für den Vortrag von Versen zwischen 12 und 17 Silben ausgehen (...) ist eine solche Mittelzäsur eine zusätzliche Möglichkeit zur Sinn-gliederung und Pausenmarkierung' 'When we take 12 to 17 syllables to be the average human breathing capacity for the recitation of verses (...) then we could consider such a middle caesura a supplementary possibility for a division according to sense and for the marking of pauses' (Eideneier 1999: 104). Furthermore, a boundary pause can be assumed, not only between the two parts divided by the caesura, but also between two verses.

As such, we can derive some prosodic information from purely written texts. This is an important fulfilment for a successful application of the prosodic criterion employed in the modern typology of clitic doubling (cf. section 5.4).

\subsection{Distribution of clitic pronouns}

However, before applying this typology to my corpus, a short overview on the distribution of clitic pronouns in Medieval Greek is required, for their behaviour differs from the Modern Greek clitic pronouns. ${ }^{9}$ In Modern Greek, the position of clitic pronouns simply depends on the (non-) finiteness of the verbal form. In finite clauses, clitic pronouns appear before the verb (cf. section 3.2), whereas postverbal clitic pronouns are the norm after gerunds and imperatives (Philippaki-Warburton 1994).

\footnotetext{
${ }^{8}$ LR: 4013 verses, edition of Lendari (2007); BC: 1350, Egea (1998); AB: 1926, Agapitos, Hult \& Smith (1999). All these editions can be found unabridged on the Thesaurus Linguae Graecae.

${ }^{9}$ By Modern Greek, I actually mean Standard Modern Greek, for some Modern Greek dialects (e.g. Cappadocian, Pontic) present differences from the standard language with regard to the distribution of clitic pronouns.
} 
In Medieval Greek, the situation is more complex, which probably explains the remarkable interest in Medieval Greek clitic pronouns in recent years. ${ }^{10}$ The position of Medieval Greek clitic pronouns is regulated by a number of syntactic and pragmatic factors. ${ }^{11}$ As pioneer Mackridge $(1993 ; 1995 ;$ 2000) has observed, the default position for clitic pronouns in finite clauses is postverbal. However, the clitic pronoun can be attracted to preverbal position by certain elements immediately occurring before the finite verb. Briefly, these triggering elements consist of so-called 'function words' (especially subordinators) and 'preferential words' (e.g. demonstratives; see Dover 1960), but also 'ad hoc focalized constituents' can be responsible for preverbal clitic pronouns (see Soltic 2012). These last are purely lexical constituents which constitute the focus (as opposed to the topic) of the utterance (see Condoravdi \& Kiparsky 2004; Revithiadou \& Spyropulos 2006), for instance:

(6) 'Eßraíver †

Evjéni i

Comes out $A R T_{N O M}$ girl $_{N O M}$

'The girl came out, when she hear

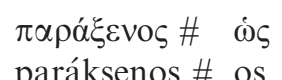

when $_{S U B}$ CL,

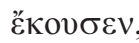

$\theta \omega \rho \varepsilon \hat{\imath}$

$\mu \varepsilon($ LR 2861)

m'

ékusen,

Өorí

me

heard

sees

$C L, A C C$

In this verse, a function word, i.e. the temporal subordinator $\dot{\omega} \varsigma / \mathrm{os}$, attracts the clitic $\mu(\varepsilon) / \mathrm{m}(\mathrm{e})$ to preverbal position. If, however, no such triggering word precedes the verb, the pronoun stays postverbal, as is the case with the second $\mu \varepsilon / \mathrm{me}$.

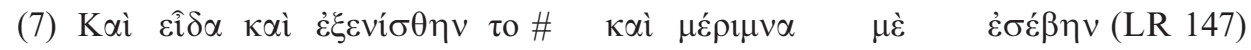

Ke íða ke eksenís $\theta$ in to \# ke mérimna me esévin

And saw and admired $C L, A C C$ and anxiety ${ }_{N O M} C L, A C C$ entered

'And I saw and admired it and anxiety took me'

In the first part of the verse, the clitic pronoun $\tau_{\mathrm{o}} /$ to is found in its normal postverbal position. ${ }^{12}$ In the second part, $\mu \varepsilon \dot{c} /$ me appears before the verb because of the ad hoc focalized subject $\mu \varepsilon \dot{\varepsilon} \rho \mu v \alpha /$ mérimna.

The fact that the position of Medieval Greek clitic pronouns is regulated by other mechanisms than that of the Modern Greek ones has consequences for the application of Janse's typology (cf. sections 3.2; 5.4). Whereas in Janse's clitic-doubling typology of Modern Greek only one possible position for the pronoun is given (preverbal because finite verbs follow), in Medieval Greek more variation is found (preverbal and postverbal). This difference, however, is of course merely superficial. As a matter of fact, my corpus contains exactly the same four structures of clitic doubling which have been identified for Modern Greek.

\subsection{Typology}

\subsubsection{Statistics}

My corpus abounds with clitic doubling: of a total of 2,194 clitic pronouns, more than 10 per cent are found in a doubling structure. ${ }^{13}$ Table 1 reveals that the dislocation type is more

\footnotetext{
10 Among others: Ramoutsaki (1996); Condoravdi \& Kiparsky (2004); Pappas (2004); Thoma (2007); Vejleskov (2005); Revithiadou \& Spyropoulos (2006; 2008); for a detailed bibliography, see Soltic (2012).

11 As pointed out by an anonymous referee, these pragmatic factors cannot be completely detached from syntax, since the fact that the preverbal triggering word must precede the verb is a very important syntactic restriction. Pappas (2004) in particular minimizes the impact of pragmatics on the position of the Medieval Greek clitic pronouns. He believes a number of preverbal constituents may or may not trigger preverbal clitic pronouns, independently of whether they are focalized or not.

${ }^{12}$ An anonymous referee brought to my attention that this construction, in which the clitic pronoun seems to scope over both parts of the co-ordination, is not possible in Modern Greek.

13 Beside 219 clauses with finite verbs, this table includes 21 imperatives and three infinitives.
} 


\begin{tabular}{lr} 
Table 1. Total doubled NPs: 241 \\
\hline Topicalization & $53(22 \%)$ \\
Topic left-dislocation & $110(45.6 \%)$ \\
Backgrounding & $39(16.2 \%)$ \\
Topic right-dislocation & $39(16.2 \%)$ \\
\hline
\end{tabular}

popular than the structure without a boundary pause (topic left-dislocation and topic rightdislocation: $61.8 \%$ ). Moreover, the doubled objects occurring at the left side of the verb prevail over those found at the right side (VO: topicalization and topic left-dislocation: $67.6 \%$ ).

\subsubsection{Examples}

Below I give two examples of each structure: first one with a postverbal clitic pronoun, then one with a preverbal one.

\section{Topicalization}

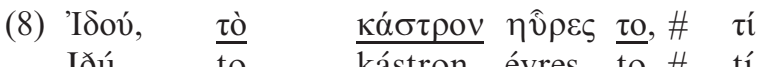
Iðú, $\quad \underline{\text { to }} \quad \underline{\text { kástron }}$ évres to,$\#$ tí akarterís, ipé mas

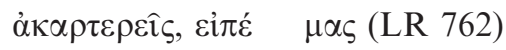
Look $_{I M P} \overline{A R} T_{A C C} \overline{\text { castle }_{A C C}}$ found $\overline{C L, A C C}$ why INTER wait tell $_{I M P C L, G E N}$ 'Look, the castle, you found it, what are you waiting for, tell us'

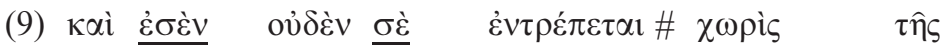 ke esén uðén se endrépete \# xorís tis vasilías and $\overline{y o u}_{A C C} N E G \quad \overline{C L}_{A C C}$ suits without $_{P R E P} A R T_{G E N}$ queen $_{G E N}$ 'and you, nothing suits you without the queen'

Topic left-dislocation ${ }^{14}$

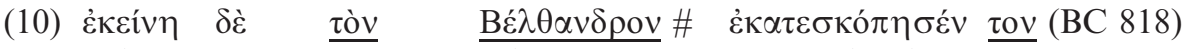

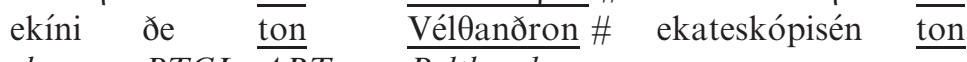
she $_{N O M}$ PTCL $\overline{A R} T_{A C C} \overline{\text { Belthandros }}_{A C C}$ saw $\quad \overline{C L}, A C C$ 'and Belthandros, she saw him'

(11)

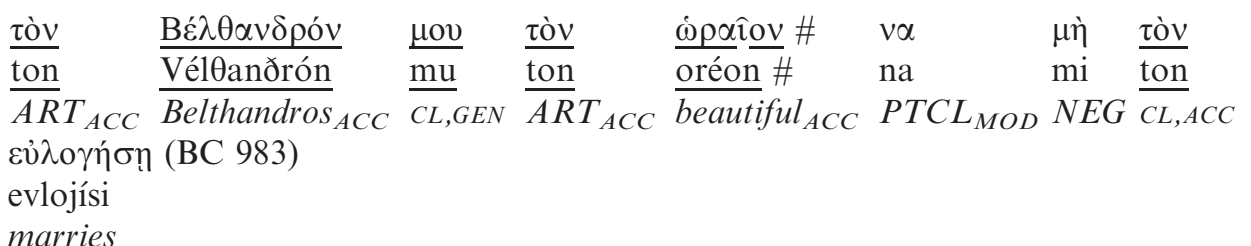
'my beautiful Belthandros, he may not join him in matrimony'

14 I have found one example in which a prepositional phrase (instead of an NP) is doubled:

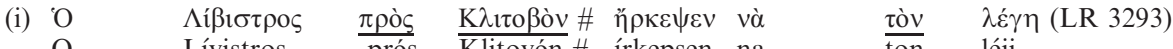 O Lívistros $\overline{\text { prós }}$ Klitovón \# írkepsen na lóji $A R T_{N O M}$ Libistros $_{N O M}$ to PREP $_{\text {Klitibos }_{A C C}}$ began PTCL MOD $_{C L, A C C}$ says 'To Klitobos, Libistros began to say to him'

In this example, the preposition $\pi \rho$ ó $/$ prós + accusative replaces the former dative in its function of indirect object. More often, however, the dative is replaced by the accusative or genitive case, which has probably caused this construction (see Manolessou \& Stamatis 2006). 
Backgrounding

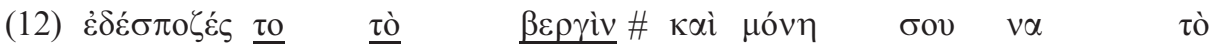

eðéspozés to to to verjín \# ke móni su na to

own $\overline{C L}, A C C \bar{A} R T_{A C C} \overline{\text { stick }}_{A C C}$ and alone $F E M$ CL,GEN PTCL MOD $C L, A C C$

' $\chi$ ฤ (BC 585)

'xis

have

'you own it, the stick, and you alone have it'

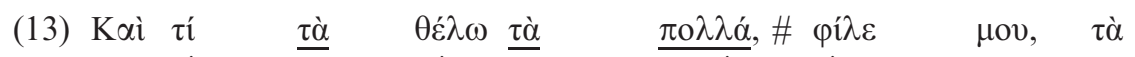

Ke tí ta $\quad \underline{\text { ta }}$ élo ta

And why $_{I N T} \overline{C L}, A C C$ want $\bar{A} R T_{A C C}$ great $_{A C C}$ friend $_{V O C} C L, G E N$ ART $A C C$

غ̇V $\quad \mu \dot{\varepsilon} \sigma \omega ;($ LR 2036)

en méso?

in $_{P R E P}$ middle $_{D A T}$

'And why would I want (to tell) them, the great things, my friend, the things (that happened) in the meantime?'

\section{Topic right-dislocation}

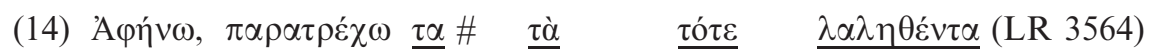

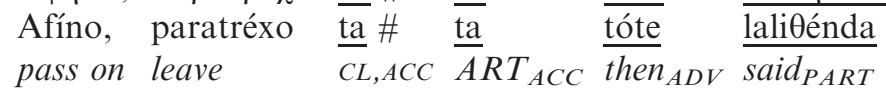

'I pass on, I leave them, the things said at that moment'

(15) Kà̀ ó

$\mathrm{Ke} \mathrm{O}$

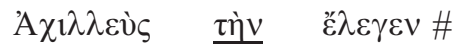

Axilléfs $\quad \underline{\text { tin }}$ élejen \#

And $A R T_{N O M}$ Achilles $_{N O M} \overline{C L}, A C C$ spoke $A R T$

'And Achilles spoke to her, the sun born girl'

In a number of examples, the co-referential clitic pronoun shows no agreement in gender or number with the right-dislocated object, more concretely: with the second object, which is added to the first one (usually an emphatic pronoun). This seems to point to a corrective function of the doubled NP (cf. section 6.3), for example:

(16)

\begin{tabular}{|c|c|c|c|c|c|c|c|}
\hline$\Omega \varsigma$ & $\beta \alpha \sigma \imath \lambda \varepsilon^{\prime} \alpha \nu$ & $\mu \grave{\varepsilon}$ & 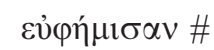 & $\dot{\varepsilon} \mu \grave{\varepsilon} \nu$ & $\kappa \alpha i ̀$ & $\tau \underline{\eta} v$ & 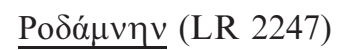 \\
\hline Os & vasilían & $\underline{\mathrm{me}}$ & efímisan \# & emén & & $\overline{\operatorname{tin}}$ & Roðámnin \\
\hline & king & $\overline{C L}, A C C$ & honoured & $m e_{A C C}$ & and & $\overline{A R} T_{A C C}$ & $\overline{\text { Rodamne }}_{A C C}$ \\
\hline
\end{tabular}

(17)

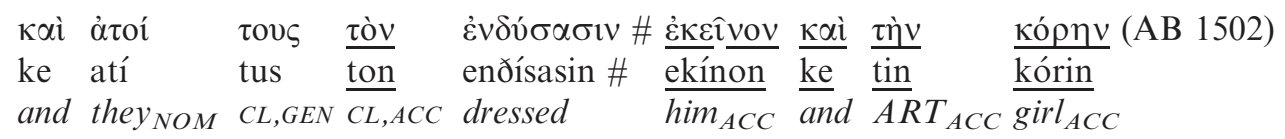

'his men dressed him, him and the girl'

Interestingly, this mismatch between clitic pronoun and NP only occurs in my corpus in structures of topic right-dislocation and not in examples of backgrounding. This confirms the observation that the lack of agreement between the NP and the clitic pronoun is normally not allowed in backgrounding constructions, while it is possible in topic right-dislocations (Krapova \& Cinque 2008: 260; cf. section 4.2). 


\subsection{Function: topic marker}

It is not only the modern typology of clitic doubling that can be applied to vernacular Medieval Greek; its modern function as a topic marker can be adopted as well. As mentioned above, I use the term 'topic' in the sense of Gundel \& Fretheim (2004): as relationally given information opposed to 'focus'. As we saw in section 5.3, Medieval Greek clitic pronouns can be attracted to preverbal position by ad hoc focalized constituents among others. Hence, their position is diagnostic for the topic/focus pair. Therefore, in section 5.5.2, I illustrate by means of the position of the clitic pronouns that doubled objects require a topical reading.

First, however, it is shown that doubled objects are almost always referentially given in my corpus and applied to Chafe's (1994) referential continuum, constitute active or semi-active information (section 5.5.1), which is confirmed by the frequent doubling of demonstratives referring back to the preceding context. Since a logical correlation exists between referential and relational givenness (cf. section 3), this constitutes a second, albeit more tentative, argument for the interpretation of doubled objects as topics.

\subsubsection{Chafe's activation statuses (referential givenness)}

Since topics, as relationally given information, are largely determined by the speaker (cf. section 3), it seems that we should resort to the concept of referential givenness in order to objectively investigate written texts: 'focus structure is not automatically fixed by the textual context, or even by the extralinguistic context, because it depends on what the speaker has in mind and wants to express' (Condoravdi \& Kiparsky 2004: 166). Therefore, I have analysed the doubled objects in my corpus in terms of referential givenness/newness, i.e. 'through the actual presence or derivability of an element in the context. Whether this reflects the speaker's assumptions is not really relevant here' (Geluykens 1992: 12). For this purpose, I have relied on the well-known continuum of 'activation statuses' developed by Chafe (1994), according to which information can be active, semi-active or inactive, which correlates with a tripartite given-accessible-new distinction.

However, the attribution of a doubled object in one of these three categories still involves personal interpretation. In order to reduce the subjectivity of the task, I have outlined clear criteria: all objects which have been mentioned in the preceding two verses, either literally or as a synonym, are considered active information. Inactive concepts, on the other hand, are neither present in nor derivable from the preceding context. The intermediate category of semi-active information presents the most difficulties if one attempts to define it in a formal way: as for my corpus, I have decided that objects which have been mentioned in (approximately) the last thirty lines are to be considered semi-active. Objects which are somehow derivable from other concepts mentioned in the context are also reckoned among this category (e.g. tired $\rightarrow$ a bed). ${ }^{15}$

The results of this investigation are straightforward: in more than 90 per cent of cases, the doubled object constitutes active or semi-active information: 'clitic doubling marks the cliticdoubled NPs (see Table 2) as active (given) or at least semi-active (accessible) information'

\footnotetext{
15 The idea that newly introduced referents may be tied to previously uttered referents is known as 'accommodation' (Heim 1982: 238ff.). In this regard, an anonymous referee suggests that the theoretical concept of 'links' in the sense of Vallduví (1992) or Hendriks \& Dekker (1995), which has been applied to analyse Modern Greek topics subject to clitic doubling, might be revealing (Alexopoulou \& Kolliakou 2002). A crucial aspect of these analyses is that these definitions of topic necessitate picking a referent that is related to a discourse set either by means of set membership or relationally. Especially with regard to my semi-active examples, this suggestion might be useful because the doubled NP indeed often picks a referent from a discourse set rather than just a strongly activated referent.
} 
Table 2. Total doubled NPs: 241

\begin{tabular}{lclr}
\hline Active & $69(28.6 \%)$ & $\begin{array}{l}\text { Literal repetition (within last two verses) } \\
\text { Synonym (within last two verses) }\end{array}$ & $\begin{array}{r}29(12 \%) \\
40(16.6 \%)\end{array}$ \\
Semi-active & $151(62.7 \%)$ & $\begin{array}{l}\text { Literal repetition in context (approx. within last 30 verses) } \\
\text { Concept derivable from context (approx. within last 30 verses) }\end{array}$ & $\begin{aligned} 39(16.2 \%) \\
112(46.5 \%)\end{aligned}$ \\
Inactive & $21(8.7 \%)$ & & \\
\hline
\end{tabular}

Table 3. Total doubled NPs: 241

\begin{tabular}{lllll}
\hline & Topicalization: 53 & Topic left-dislocation: 110 & Backgrounding: 39 & Topic right-dislocation: 39 \\
\hline Active: 69 & $13(24.5 \%)$ & $33(30 \%)$ & $13(33.3 \%)$ & $10(25.6 \%)$ \\
Semi-active: 150 & $37(69.8 \%)$ & $65(59.1 \%)$ & $20(51.3 \%)$ & $29(74.4 \%)$ \\
Inactive: 22 & $3(5.7 \%)$ & $12(10.9 \%)$ & $6(15.4 \%)$ & $0(0 \%)$ \\
\hline
\end{tabular}

(Janse 2008: 170). ${ }^{16}$ Moreover, it should come as no surprise that semi-active information prevails over truly active concepts, as this latter kind of information is characteristically expressed by weak pronouns instead of by NPs (see Ziv 1994: 634; Givón 2001: 418; Estigarribia 2006: 133). If we relate the three categories of referential givenness/newness to the attested four types, no striking differences are detected in Table 3. In the backgrounding type, slightly more fully active NPs are found, yet this construction also contains the highest number of inactive NPs.

\subsubsection{Examples}

In this section, it makes no sense to quote only the verse containing the doubled NP. Therefore, I provide enough contextual information and the relevant passages are italicized: Active information - literal repetition

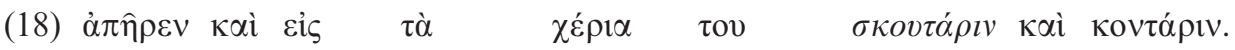
apíren $\mathrm{ke}$ is ta xéria tu skutárin ke kondárin. took and in PREP $A R T_{A C C}$ arms $_{A C C} C L, G E N$ shield $A C C$ and sword $A C C$ 'he took in his arms a shield and a sword.'

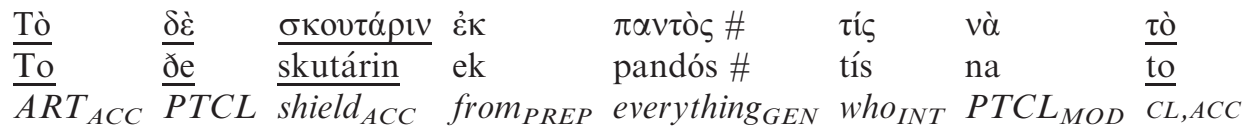
àvıб

anistorísi?

describes

'The shield, who could describe it in detail?'

(19) $o i$

oi "E

i Érotes me efónefsan ke katetrósasín me.

$A R T_{N O M}$ Cupids $_{\text {NOM }}$ CL,ACC killed and hurt CL,ACC

'The Cupids killed me and hurt me.'

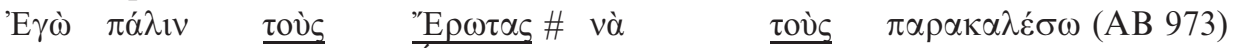

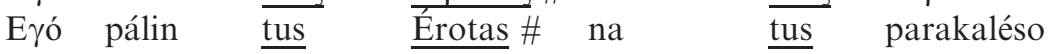

$I_{N O M} \operatorname{again}_{A D V} \overline{A R} T_{A C C} \overline{\text { Cupids }}_{A C C} P T C L_{M O D} \overline{C L}_{A C C}$ implore

'I again, the Cupids, I will implore them'

\footnotetext{
16 Note, however, that this quotation confuses the true prerequisite for clitic doubling, i.e. topicalized objects, with the indirect and logical consequence of this prerequisite, i.e. referentially given objects.
} 
Active information - synonym:

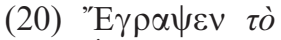

É $\gamma$ rapsen to

$\pi \imath \tau \tau \alpha \dot{\kappa} \kappa l$

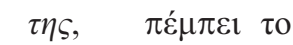

$\pi \rho \grave{s} \quad \dot{\varepsilon} \mu \varepsilon ́ v \alpha$

Wrote

pittákin tis, pémbi to

prós eména

'She wrote her letter, she sent it to me'

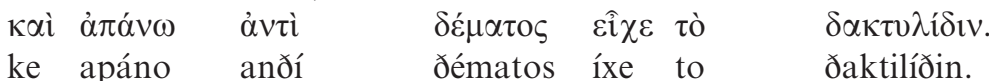

and above $_{A D V}$ instead $_{P R E P}$ string $_{G E N}$ had $A R T_{A C C}$ ring $_{A C C}$

'and on top of the string it had the ring.'

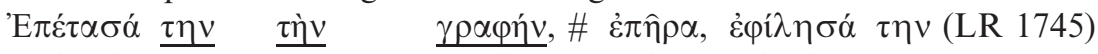

Epétasá tin tin $\underline{\text { tin }}$ rafín, \# epíra, efílisá tin

Took $\overline{C L}, A C C \overline{A R T}_{A C C} \overline{\text { letter }}_{A C C}$ held kissed $C L, A C C$

'I took it, the letter, I held (it), I kissed it'

(21)

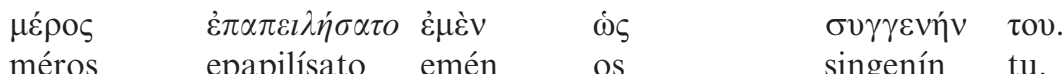

méros epapilísato emén singenín tu.

on the other hand ${ }_{A D V}$ threatened $m_{A C C} a_{P R E P}$ relative $A C C C L, G E N$

'on the other hand, he threatened me as his relative.'

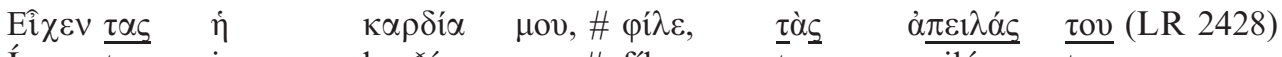

Íxen tas i karðía mu, \# fíle, $\overline{\text { tas }} \underline{\text { apilás }} \underline{\text { tu }}$

Had $\overline{C L, A C C}$ ART $T_{N O M}$ heart ${ }_{N O M} C L, G E N$ friend ${ }_{V O C} \overline{A R} T_{A C C} \overline{t h r e a t s}_{A C C} \overline{C L, G E N}$

'My heart retained them, friend, his threats?'

Semi-active information - literal repetition in context:

(22) $\dot{\varepsilon}$

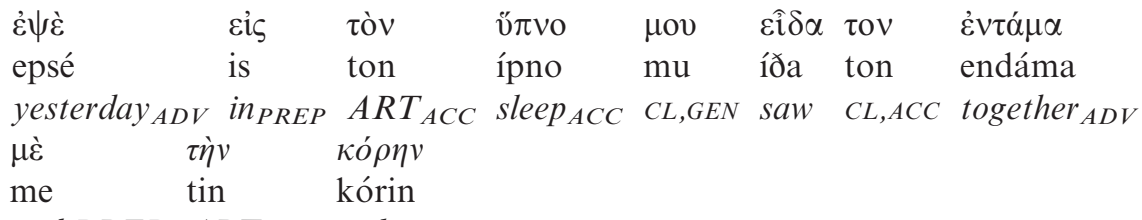

withPREP ART $A C C$ girl $_{A C C}$

'yesterday in my sleep I saw him together with the girl'

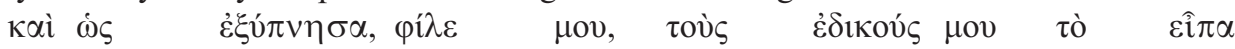

ke os eksípnisa, fíle mu, tus eðikús mu to ípa

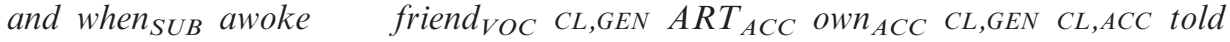

'and when I awoke, my friend, I told it to my men'

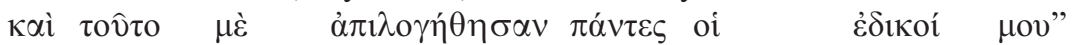

ke túto me apilojí日isan pándes i eðikí mu"

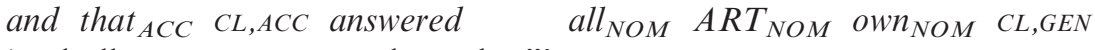

'and all my men answered me that"'

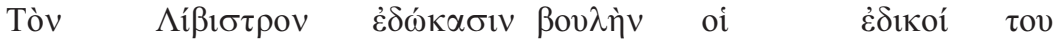

Ton Lívistron eðókasin vulín i eðikí tu

$A_{A C C}$ Libistros $_{A C C}$ gave advice $_{A C C} A R T_{N O M}$ own $_{N O M} C L, G E N$

'His men gave Libistros advice'

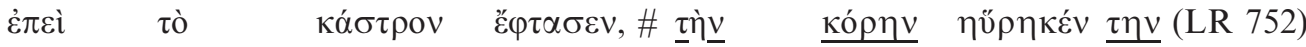

epí to kástron éftasen, \# tin kórin évrikén tin

after $_{S U B} \quad A R T_{A C C}$ castle $_{A C C}$ reached $\overline{A R} T_{A C C} \overline{\text { girl }_{A C C}}$ found $\overline{C L}, A C C$

'after he had reached the castle, the girl, he found her' 
Concept derivable from context:

(23)

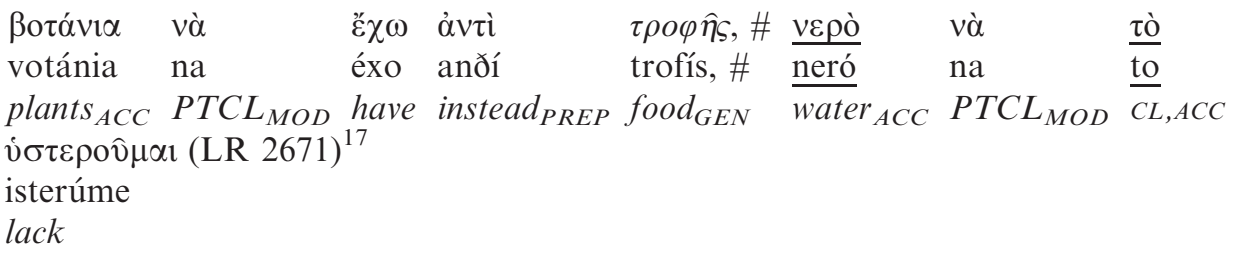

'I had plants instead of food, water, I was lacking it'

Inactive information: even in this category of objects containing inactive information, one can doubt whether the doubled NPs are truly 'irrecoverable' from the context. In some cases, one could tentatively argue that the NPs do present information derivable from the preceding context, for instance:

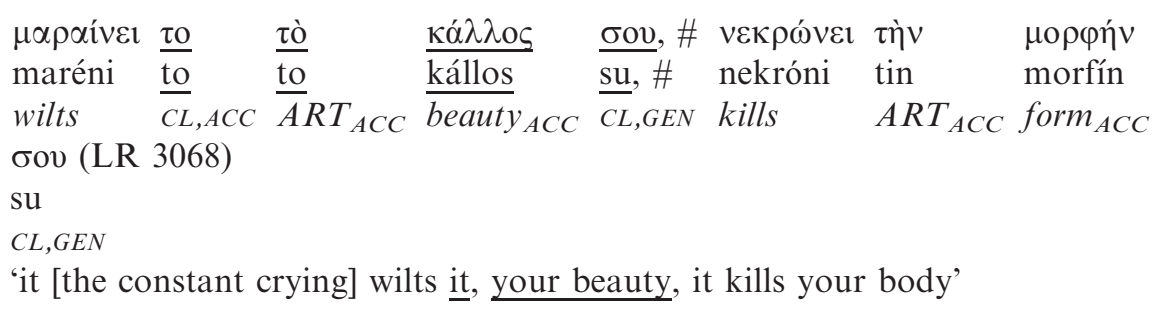

The ladies-of-the-bedchamber of the king who has abducted Rodamne are trying to

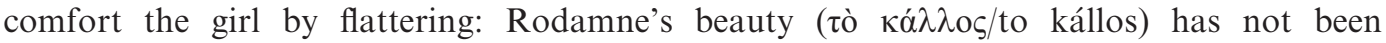
mentioned in the context and there seems no word present referring to her beauty, yet one could say the concept 'beauty' is inextricably connected with the appearance of the girl (cf. use of the definite article $\tau$ ó/to). Rodamne is constantly described in terms of beauty in LR (cf.

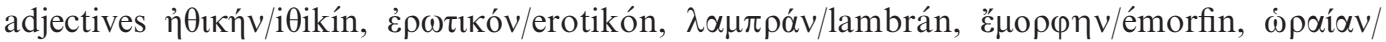

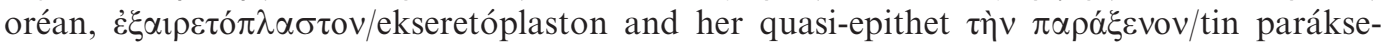
non) and her beauty is of course the reason why she has been abducted.

\subsubsection{Demonstrative pronouns}

However, more secure evidence on the referentially given character of (most) objects is given by the use of anaphoric demonstrative pronouns. As these demonstrative pronouns refer back to the preceding context, they can be conceived of as signs of old information. The fact that no less than 31 doubled objects $(12.9 \%$ ) consist of a demonstrative (autonomous use) or are accompanied by a demonstrative (adjectival use) corroborates the observed tendency that doubled objects constitute (semi-)active information.

Autonomous use:

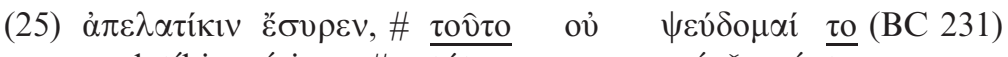
apelatíkin ésiren, \# túto ou psévðomé to stick $_{A C C}$ hauled that ${ }_{A C C} N E G$ invent $\overline{C L}_{A C C}$ 'he hauled his stick, that, I do not invent it'

\footnotetext{
17 This example of topicalization involves a bare indefinite. The other four examples of doubled bare NPs in my corpus all present cases of topic left-dislocation. Interestingly, this fits the observation made for Modern Greek that the grammaticality of a doubled bare NP may depend on the specific type of clitic doubling, more specifically, that a doubled bare NP is ungrammatical with backgrounding (cf. fn. 6).
} 
Adjectival use:

(26)

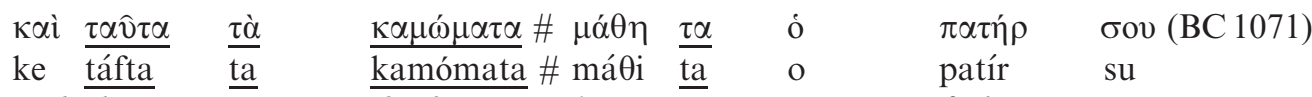
and $\overline{\text { those }}_{A C C} \bar{A} R T_{A C C} \overline{\text { deeds } A C C}$ learns $\overline{C L, A C C}$ ART $T_{N O M}$ father $_{N O M} C L, G E N$ 'and those deeds, your father will learn them'

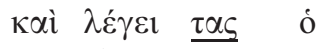

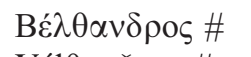

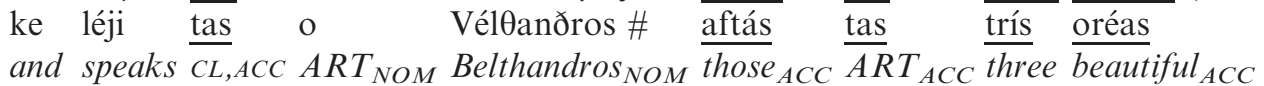

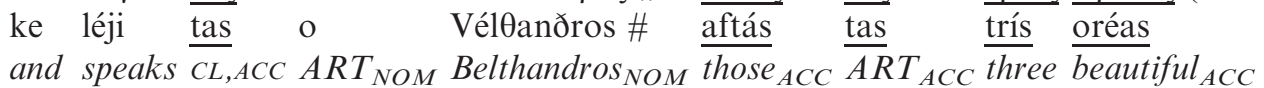
$\underline{\alpha u ̉ \tau o ̀ s ~} \quad \underline{\tau \alpha ̀ s}$

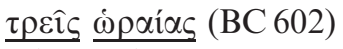
'and Belthandros spoke to them, those three beautiful girls'

\subsubsection{Apparent exception: addition in the form of a relative clause?}

In some 10 per cent of the examples, the NP is modified by a relative clause. NPs + relatives are not confined to a certain type of clitic doubling; they are found in all four types, although topic left-dislocation is prevalent. ${ }^{18}$ At first sight, these constructions might seem to contradict the thesis that doubled NPs consist of topicalized and thus -given the correlation between the two concepts- usually referentially given information, since relative clauses might be expected to contain new, additional information (see Table 4).

I give an example of each type:

(28)

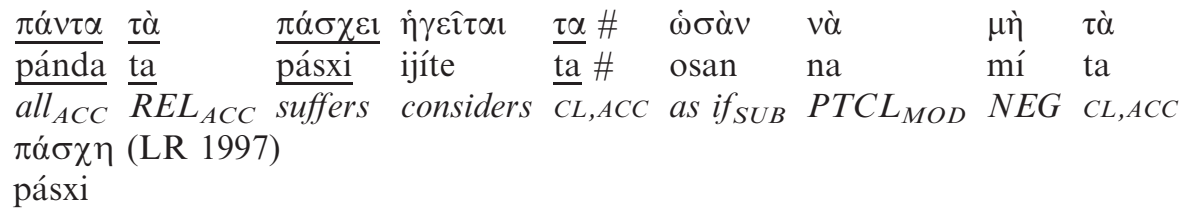

suffers

'all that he has suffered, he considers it as if he has not suffered it'

(29)

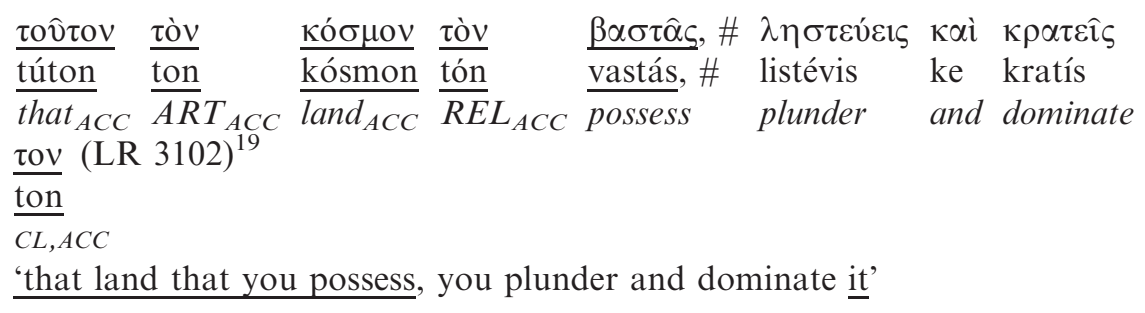

Table 4. Total doubled NPs modified by relative clause: 24

\begin{tabular}{lc}
\hline Topicalization & $1(4.2 \%)$ \\
Topic left-dislocation & $19(79.2 \%)$ \\
Backgrounding & $2(8.3 \%)$ \\
Topic right-dislocation & $2(8.3 \%)$ \\
\hline
\end{tabular}

${ }^{18}$ I have also found 35 examples in which the relative clause does not modify an NP, but is 'headless'. An example of the doubling of a so-called free relative clause is the following:

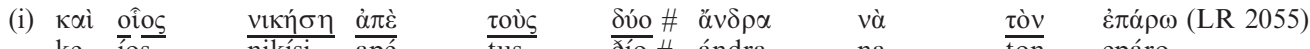

ke íos $\overline{\text { nikísi }} \overline{\text { apé }} \overline{\text { tus }}$ oío \# ándra na $\overline{\text { ton }}$ epáro

and $\overline{R E} L_{N O M} \overline{\text { wins }} \quad \overline{\text { from }}_{P R E P} \overline{A R} T_{A C C} \overline{\text { two }}$ husband $_{A C C} P T C L_{M O D} \overline{C L, A C C}$ take

'and the one of the two who will win, him I will take as my husband'

These examples were not included in my statistics, as they do not involve NPs but clauses (cf. section 5.4.1). As is the case for the NPs modified by a relative clause, the majority $(25=71.4 \%)$ involves topic left-dislocation.

19 Cf. section 5.5.1.2: demonstrative pronoun. 


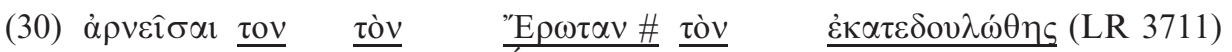

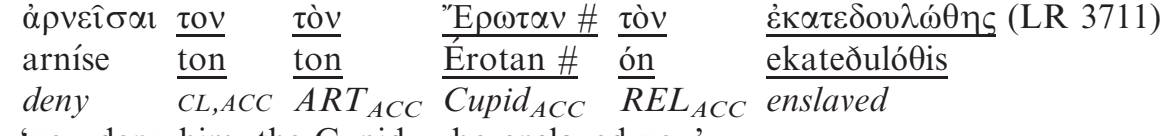

'you deny him, the Cupid, who enslaved you'

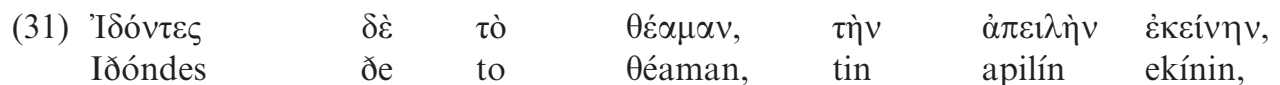

Having seen PART $_{\text {PTCL }}$ ART $_{A C C}$ spectacle $_{A C C}$ ART $_{A C C}$ threat $_{A C C}$ that $_{A C C}$

'After they had seen the spectacle, that threat,'

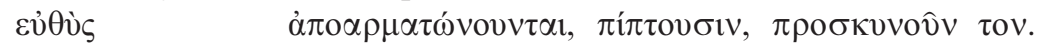

ef $\theta$ ás apoarmatónunde, píptusin, proskinún ton.

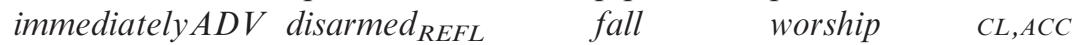

'they immediately disarmed themselves, they fell, they worshipped him [Achilles].'

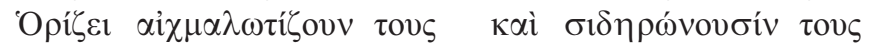

Orízi exmalotízun tus ke siðirónusín tus

Orders emprison $\quad C L, A C C$ and chain $C L, A C C$

'He ordered to make them prisoners of war and to chain them'

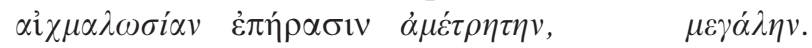

exmalosján epírasin amétritin, meyálin.

captivity $_{A C C}$ took immeasurable ${ }_{A C C}$ enormous $_{A C C}$

'they took an immeasurable, enormous captivity.'

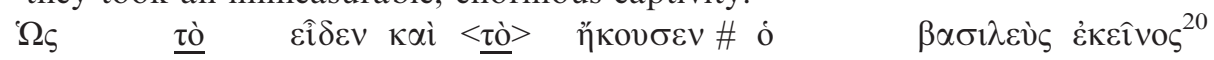

Os $\quad \underline{\text { to }}$ íđen ke $\langle\overline{\text { to }}>$ íkusen \# o

When $_{S U B} \overline{C L}, A C C$ saw and $C L, A C C$ heard ART NOM king $_{\text {NOM }}$ that $_{N O M}$

'When he saw it and heard it, that king'

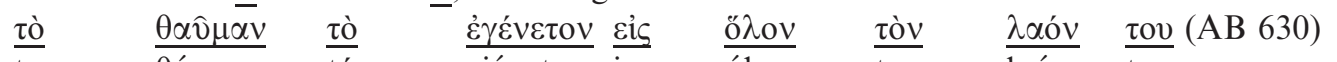

to $\overline{\text { távma }}$ tó $\quad \underline{\text { ejéneton }} \overline{\text { is }} \quad \overline{\text { ólon }} \quad \overline{\text { ton }}$ laón tu

$\overline{A R T}_{A C C} \overline{\text { wonder }}_{A C C} \bar{R} E L_{A C C} \overline{\text { happened }}_{\text {to }}{ }_{P R E P} \overline{\text { whole }}_{A C C} \overline{A R T_{A C C} \overline{r a c e}_{A C C} C L, G E N}$

'the wonder which happened to his whole race'

However, in all these examples, the NP is modified by a restrictive relative clause, which by definition renders the noun definite. Moreover, the information provided in the relative clause is usually already known. As Table 5 reveals, the doubled NPs + relative clause do not present more inactive information than the 'normal' doubled NPs do.

The context of our last example above, for instance, describes how Achilles conquers the whole army of a hostile king and makes them prisoners of war. Thus, tò $\theta \alpha \hat{v} \mu \alpha v /$ to

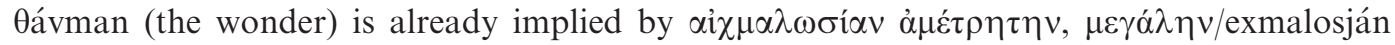
amétritin, meyálin (immeasurable, enormous captivity). A comparable example is the next one:

Table 5. Total doubled NPs modified by relative clause: 24

\begin{tabular}{lr}
\hline Active & $5(20.8 \%)$ \\
Semi-active & $15(62.5 \%)$ \\
Inactive & $4(16.7 \%)$ \\
\hline
\end{tabular}

${ }^{20}$ Cf. section 6.3.2: dislocated subject. 
(32) $\mathrm{A}(\mathrm{a})$

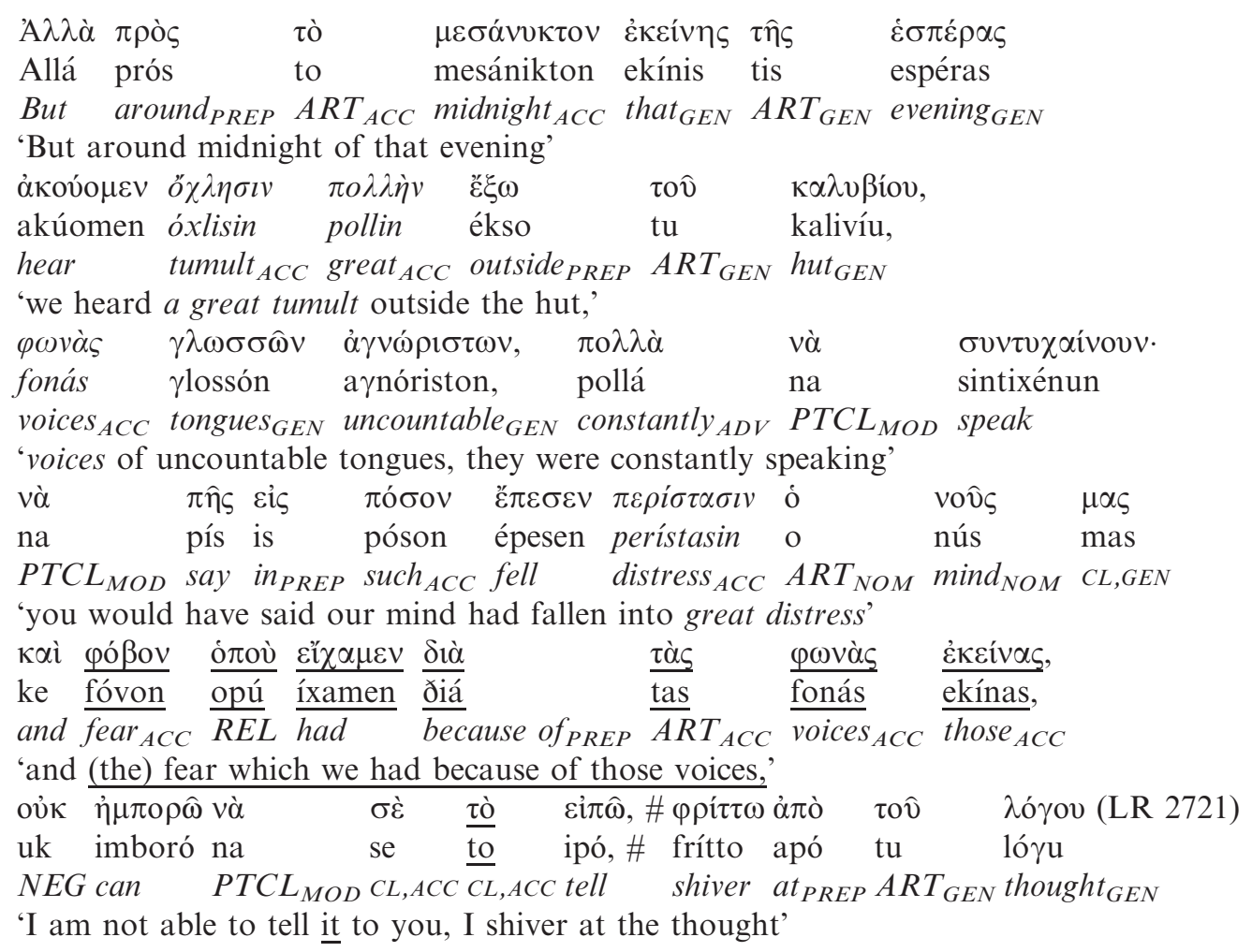

The (bare) NP $\varphi$ ó $\beta$ v/fóvon (fear) can be derived from the preceding context, i.e. ó $\chi \lambda \eta \sigma \mathrm{v}$ $\pi \mathrm{o} \lambda \lambda \eta \dot{\eta} v / o$ olisin pollín (great tumult) and $\pi \varepsilon \rho i \sigma \tau \alpha \sigma v /$ perístasin (distress); the NP in the

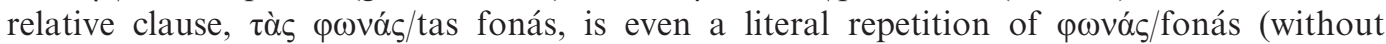

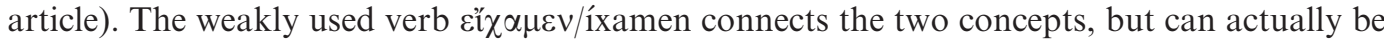

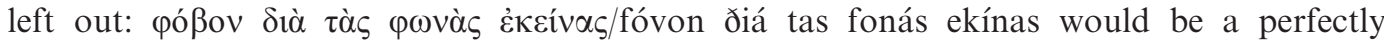
understandable utterance. I give two other examples of NPs + relative clauses in which the verbs are quite natural and can actually be predicted:

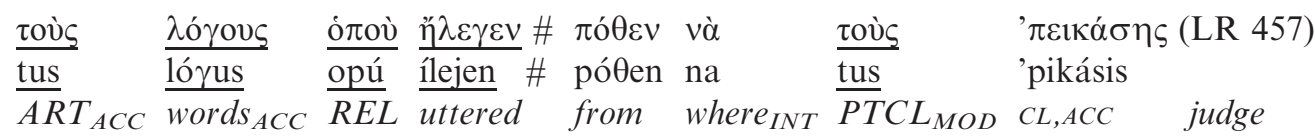
'the words he uttered, from where you should have judged them'

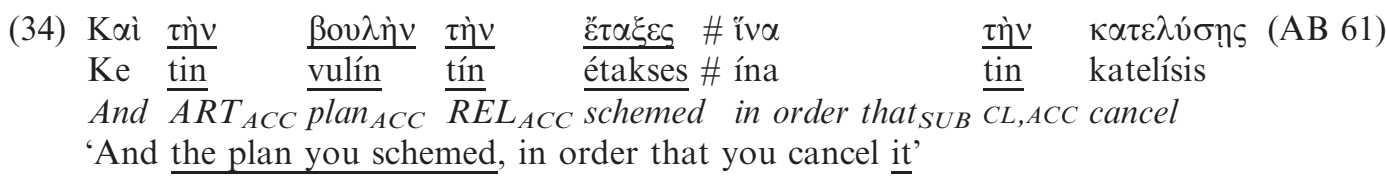

Thus, these examples are in no way exceptions.

\subsubsection{Position clitic pronouns in $O V$-doublings (relational givenness)}

However, the strongest evidence that doubled objects constitute topics is given by the position of the co-referential clitic pronouns. We have seen that constituents occurring immediately 
Table 6. Total OV doubling without intervening constituent: 68

\begin{tabular}{lll}
\hline & Preverbal pronoun (OclV): 3 & $\begin{array}{l}\text { Postverbal pronoun } \\
\text { (OVcl): 65 }\end{array}$ \\
\hline Topicalization: 37 & $3^{21}$ & 34 \\
Topic left-dislocation: 31 & 0 & 31 \\
\hline
\end{tabular}

Note: $\mathrm{cl}=$ clitic pronoun.

Table 7. Total OV doubling with intervening constituent: 95

\begin{tabular}{lll}
\hline & $\begin{array}{l}\text { Preverbal pronoun } \\
([\mathrm{X}] \mathrm{OXclV}): 87\end{array}$ & $\begin{array}{l}\text { Postverbal pronoun } \\
([\mathrm{X}] \mathrm{OXVcl}): 8\end{array}$ \\
\hline Topicalization: 16 & 16 & 0 \\
Topic left-dislocation: 79 & 71 & 8 \\
\hline
\end{tabular}

before the verb can attract clitic pronouns into preverbal position, but only if these constituents - including objects - function as focus of the utterance (cf. section 5.3). If doubling is indeed linked to topicality, we expect that all doubled objects occur with postverbal pronouns, since preverbal pronouns are associated with focalized objects. This expectation can of course only be checked for those types of clitic doubling in which the object stands to the left of the verb (OV), i.e. topicalization and topic left-dislocation (see Table 6). Moreover, the examples in which another constituent intervenes between the preposed object and the verb must be excluded, as this constituent can be focalized and as such attract the pronouns into preverbal position. The expectation is borne out: no less than 95.5 per cent of the doubled objects occur with a postverbal clitic pronoun. However, it is also interesting to have a look at the examples in which another constituent does intervene between the doubled object and the verb $(\mathrm{OXV})$,

In 91.6 per cent of the examples, preverbal clitic pronouns are found. Often, the intervening element $(\mathrm{X})$ is a function word or a preferential word, which is responsible for the preverbal position of the clitic pronoun (cf. section 5.3), for example: (Table 7)

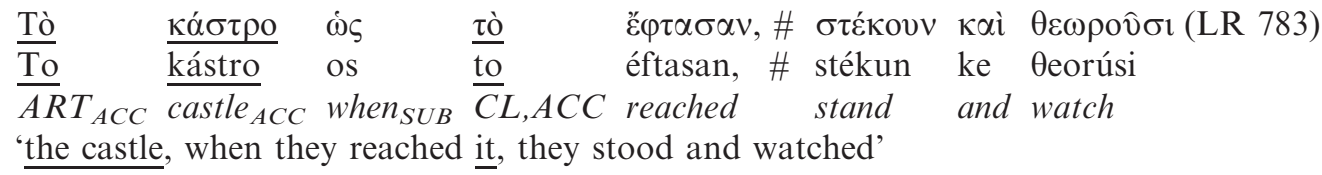

As mentioned above (section 5.3), it is not only function/preferential words that attract clitic pronouns into preverbal position. Preposed ad hoc focalized constituents are also associated with preverbal clitic pronouns (see Condoravdi \& Kiparsky 2004; Revithiadou \& Spyropulos 2006; Soltic 2012). This is the case for the examples below: the intervening element (in bold) is a lexical constituent which constitutes the focus of the utterance. Usually, it constitutes the subject of the sentence, for example:

21 The three exceptions (LR 3147, LR 3241, LR 3343) all concern ö $\lambda$ os/ólos 'whole', of which the deviant behaviour in doubling constructions has been pointed out, for instance Pappas (2004: 72): 'Furthermore, it was shown for the first time that within the factor reduplicated object, the adjective ó $\lambda$ o $\varsigma$ behaves contrary to the general pattern since one finds pronouns in the preverbal position when ö $\lambda$ os is reduplicated', see Condoravdi \& Kiparsky (2004: 171ff.). In Modern Greek too, ő $\lambda$ o $/$ ólos exhibits some idiosyncrasies: it is the only adjective which has to be doubled, yet it is stressed like a focus (Pappas 2004: 167). 


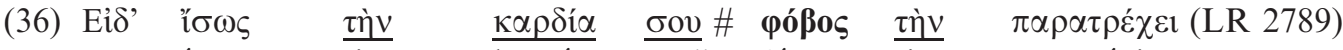

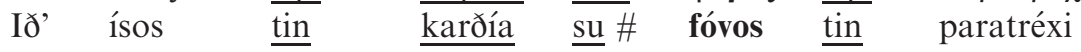 If $f_{S U B}$ maybe $_{A D V} \overline{A R} T_{A C C} \overline{\text { heart }_{A C C}} \overline{C L, G E N}$ fear $_{N O M} \overline{C L}, A C C$ passes through 'If maybe your heart, (if) fear passes through it'

However, the intervening element can also exercise other syntactic functions: I give an example of a focalized indirect object, two predicative adjuncts (an NP and a prepositional phrase) and an attributive adjunct (in the form of an adverb):

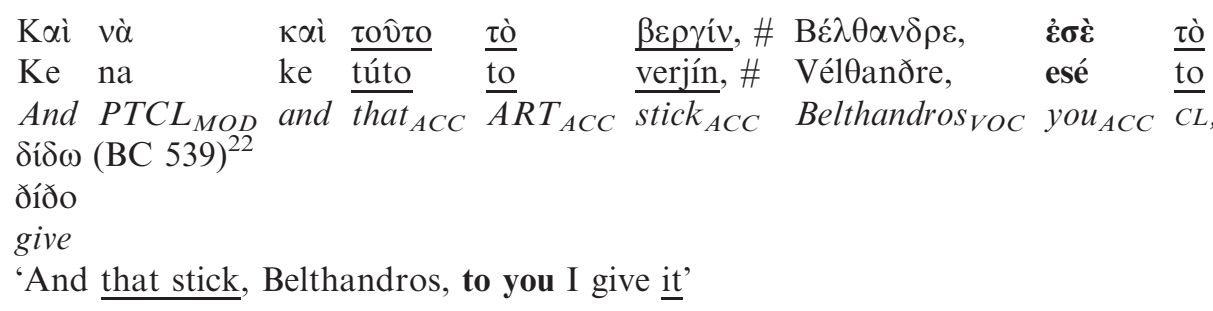

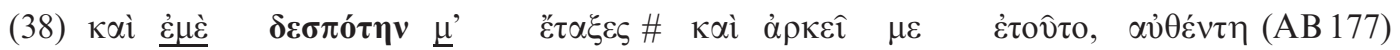
ke emé ðespótin $\underline{m}$ ' étakses \# ke arkí me etúto, afӨéndi and $\overline{m e}_{A C C}$ master $_{A C C} \overline{C L}, A C C$ appointed and suffices CL,ACC that $_{N O M}$ lord $_{V O C}$ 'and me, as a master you appointed me and that is sufficient to me, lord'

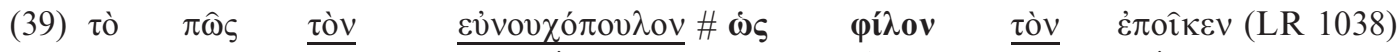 to pós ton evnuxópulon \# os fílon ton epíken $A R T$ how $_{I N T} \overline{A R} T_{A C C} \overline{\text { eunuch }_{A C C}}$ as $_{P R E P}$ friend $_{A C C} \overline{C L, A C C}$ made 'and how the eunuch, (how) he made him a friend'

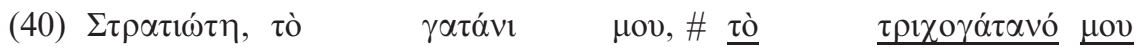

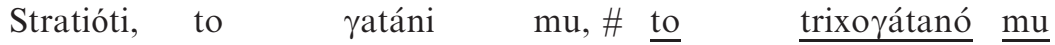 Soldier $_{V O C} A R T_{A C C}$ hairlock $A C C \quad C L, G E N \overline{A R} T_{A C C} \overline{\text { hairlock } A C C} \overline{C L, G E N}$ 'Soldier, my lock of hair, my lock of hair'

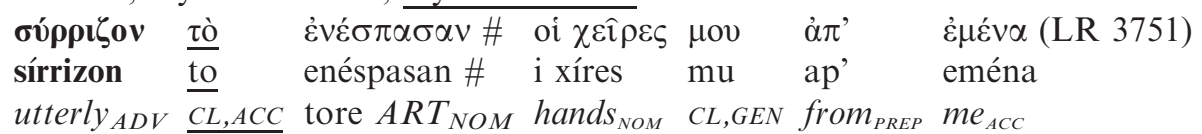

'utterly my hands tore it from me'

Thus, in the structure $\mathrm{OXclV}$, which prevails over $\mathrm{OXVcl}$, the object $\mathrm{O}$ is doubled by a clitic pronoun and must thus be conceived as the topic of the utterance, while the preverbal constituent $\mathrm{X}$ is responsible for the preverbal position of the clitic pronoun and should thus be interpreted as the focus. This pattern actually perfectly matches the scheme developed by Helma Dik $(1995 ; 2007)$ with regard to Ancient Greek information structure 'topic $>$ focus $>$ verb' and consequently reinforces our thesis that doubled objects constitute topical information in Medieval Greek too. ${ }^{23}$

\footnotetext{
${ }^{22}$ Cf. section 5.5.1.2: demonstrative pronoun.

23 Note, however, that the notions in Dik's scheme are not completely consistent: 'topic' and 'focus' are pragmatic categories, while 'verb' is a grammatical word class. In other words: verbs can also be topicalized or focalized.
} 


\section{Relation With oral Discourse}

In this section, the frequent use of clitic doubling in my corpus is related to the oral discourse which the Medieval Greek vernacular politikos stichos poetry is acknowledged to adopt. Until now, the foremost studied 'oral style marker' has been the large number of formulas (section 6.1). I argue that the linguistic phenomenon of clitic doubling can also be considered a true sign of an adopted oral discourse, for the construction is still felt typical of colloquial and thus spoken language in the Greek Middle Ages, as shown by De Boel (2008) (section 6.2). Furthermore, two constructions related to clitic doubling, especially to topic rightdislocation, are mentioned as further proof of the vernacular romances' intended oral style (section 6.3).

\subsection{Oral style markers: formulas}

The vernacular politikos stichos poetry has been related to an oral tradition. In the early days of Medieval Greek studies, enthusiastic scholars even saw a parallel between their texts and the Homeric epics (e.g. Trypanis 1963), which are acknowledged to be the result of an oral tradition. Main arguments for this comparison were the numerous formulas and the existence of the same story in various - anonymous - versions. Nowadays, a more moderate stance is taken: oral composition of the Medieval Greek politikos stichos texts is excluded, but oral performance is very likely and an oral tradition has certainly exercised a formative influence on poets who had no other models of poetic composition in the vernacular (Beaton 1986: 115; Mackridge 1990: 125). ${ }^{24}$ A distinction should thus be made between 'the physical means by which a piece of literature is composed and the type of discourse employed in that composition' (Shawcross 2005: 312). The adopted oral discourse naturally has consequences for the language of the texts: it is said to possess 'signs of the style of traditional folk poetry' (Sifakis 2001: 67). Indeed, the politikos stichos is also the common metre of the modern folk-songs, which have been recorded only from the nineteenth century on. Moreover, some verse patterns of these songs are similar to the ones found in the medieval written poetry (cf. section 6.3). How exactly, if at all, the two genres, i.e. medieval poetry and modern folk-song, are related has not yet been clarified (cf. Michael Jeffreys in personal communication 26 June 2011). ${ }^{25}$

The so-called 'style markers of orality' have especially been sought and found in the frequent formulas in the Medieval Greek poetry (e.g. Jeffreys 1973). An example of a famous intra- and intertextual formula in my corpus is the following (in italics):

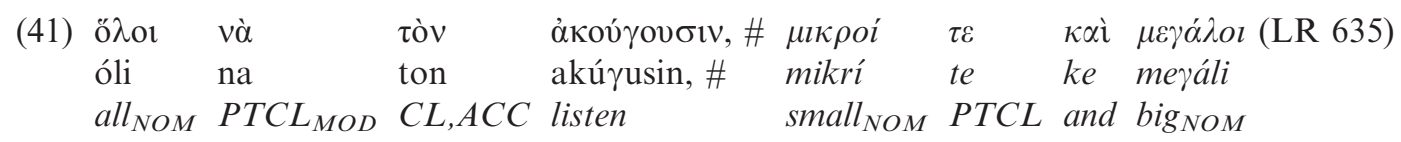

'all listen to him, small and big'

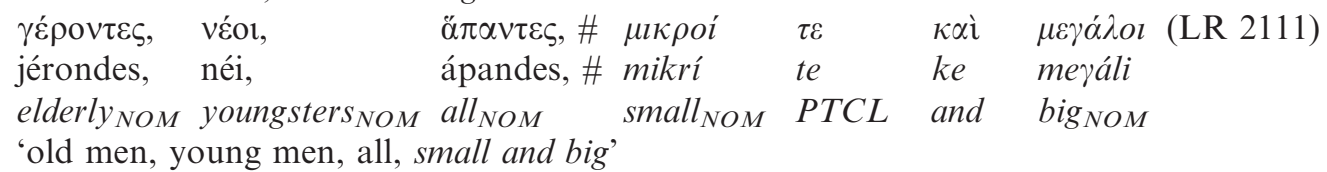

\footnotetext{
${ }^{24}$ See Sifakis (2001) for further bibliography; see Beaton (1996: 222ff.): 'The Oral Substratum of the Vernacular Romances', which specifically deals with my corpus.

${ }^{25}$ See Jeffreys (personal communication 26 June2011): 'Some striking but isolated examples of similar patterns may be found in many longer vernacular Greek poems of the fourteenth and fifteenth centuries (...) we have been repeatedly struck by their similarity to those of Modern folk-song (...). If a link is to be considered, what might it be? A simple conclusion would be that Modern Greek folk-song is the direct descendant of a written Byzantine genre (...). This seems to me extremely unlikely, as well as ideologically horrific'.
} 


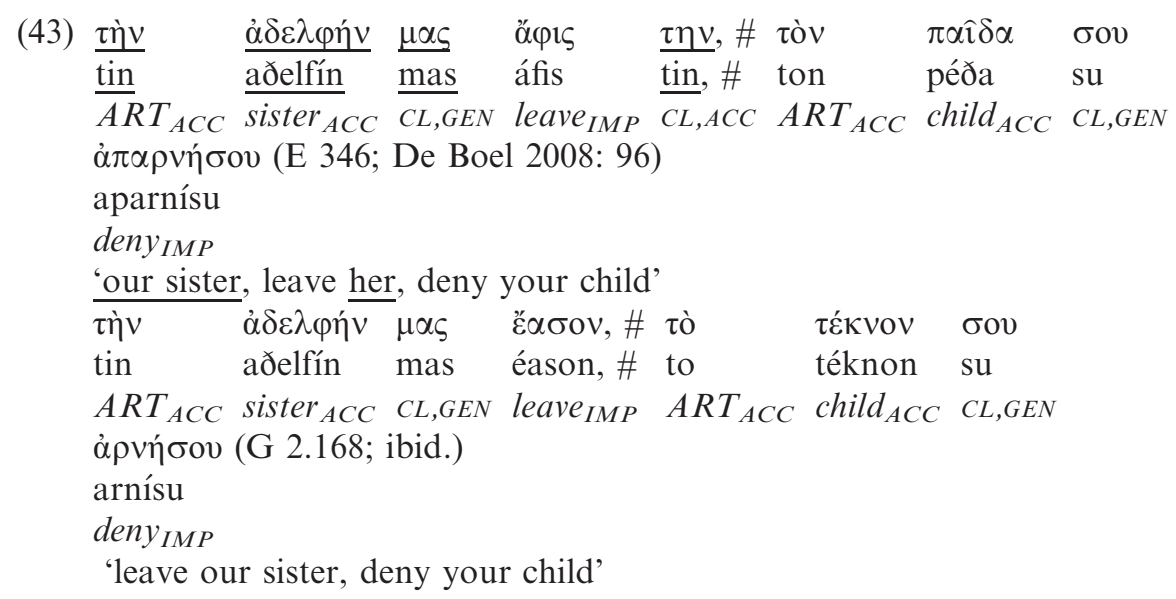

De Boel (2008) convincingly concludes that the scribe of the Grottaferrata version avoids clitic doubling in his attempt to maintain strict - written - standards, because clitic doubling is considered typical of the colloquial and thus spoken idiom: 'The clitic doubling construction is characteristic of popular Greek' (Horrocks 2010: 365). ${ }^{29}$ This popular character is presumably due to the seemingly redundant nature of clitic doubling: the clitic pronoun actually repeats an already expressed NP: 'As far as their syntactic function is concerned, Doubling Clitics are redundant, since this syntactic function is also marked in the NP' (Haberland \& Van der Auwera 1987: 330). The fact that my corpus abounds with instances of clitic doubling thus strongly confirms -from a linguistic perspective - that the authors of the verse romances deliberately adopted an oral style.

\subsection{Related structures}

Other 'oral style markers' of a more linguistic nature than the traditionally quoted formulas are dislocated genitives (cf. section 6.3.1) and dislocated subjects (cf. section 6.3.2). Both constructions are reminiscent of topic right-dislocations, especially of the special subcategory of corrective examples (cf. section 5.4.2).

\subsubsection{Dislocated genitives}

The class of dislocated genitives contains genitive NPs which clarify a co-referential possessive pronoun, i.e. a genitive clitic pronoun, standing before the boundary pause (i.e. caesura or verse end). As such, this construction clearly resembles topic right-dislocation. In the first example, the NP occupies the whole part after the caesura:

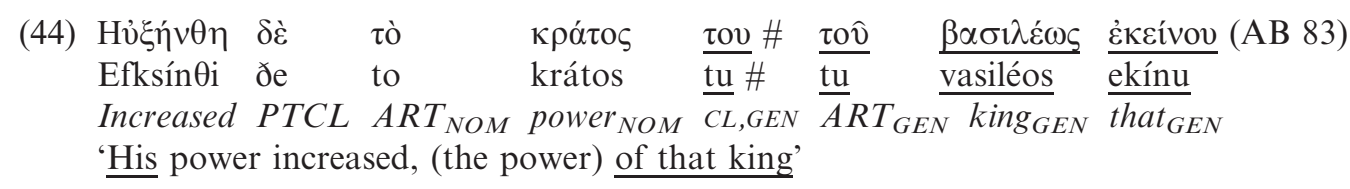

\footnotetext{
29 Interestingly, the same observation has been made with regard to some modern languages in which clitic doubling has not yet been fully grammaticalized but is still optional, for instance Bulgarian: 'C [litic] $D$ [oubling] constructions in formal and written Bulgarian are very rare, whereas they are very common in spoken and informal Bulgarian' (Guentchéva 2008: 216).
} 
In the following two examples, a parenthetic expression is found immediately after the boundary pause (respectively a verb of saying and a vocative): ${ }^{31}$

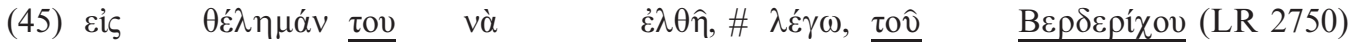

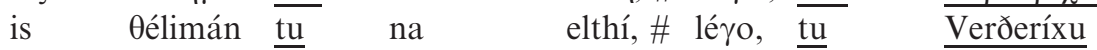
to $_{P R E P}$ will $_{A C C} \overline{C L}, G E N$ PTCL $L_{M O D}$ comes say $\bar{A} R T_{G E N} \overline{\text { Berderichos }_{G E N}}$
'she would bend herself to his will, I mean, (the will) of Berderichos'

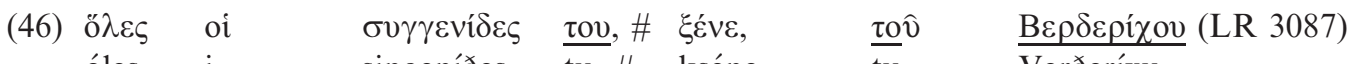

óles i singeníðes tu, \# kséne, tu

all $_{N O M} A R T_{N O M}$ relatives $_{N O M} \overline{C L, G E N}$ stranger $_{V O C} \bar{A} R T_{G E N} \overline{\text { Berderichos }_{G E N}}$

'all his relatives, stranger, (the relatives) of Berderichos'

I conclude with two examples in which the verb intervenes between the clitic pronoun and the NP:

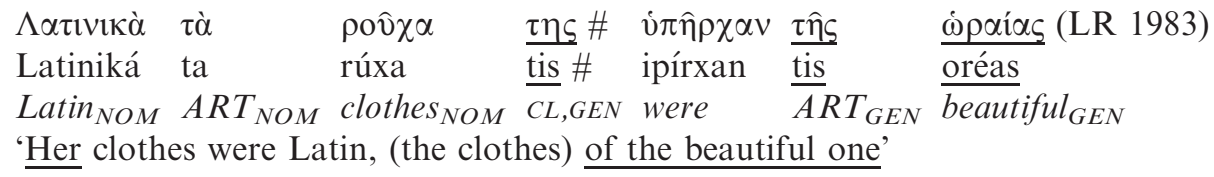

(48)

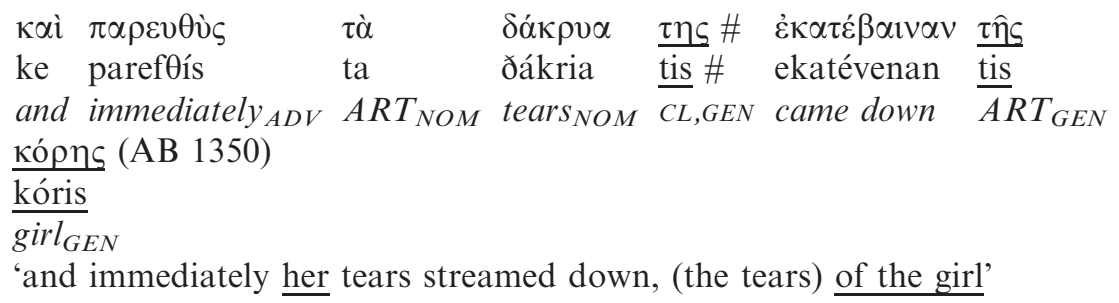

\subsubsection{Dislocated subjects}

In this construction, an NP functioning as subject is postponed after the boundary pause instead of standing next to its verb (in bold). Again, this construction bears resemblance to topic right-dislocation, despite the absence of a co-referential pronoun. The lack of a nominative pronoun functioning as provisional subject is normal, since Greek is a so-called pro-drop language: subject pronouns are only expressed if used emphatically, for one can derive the subject from the verb-morphology. ${ }^{32}$ I tentatively consider the following examples as right dislocations:

(49)

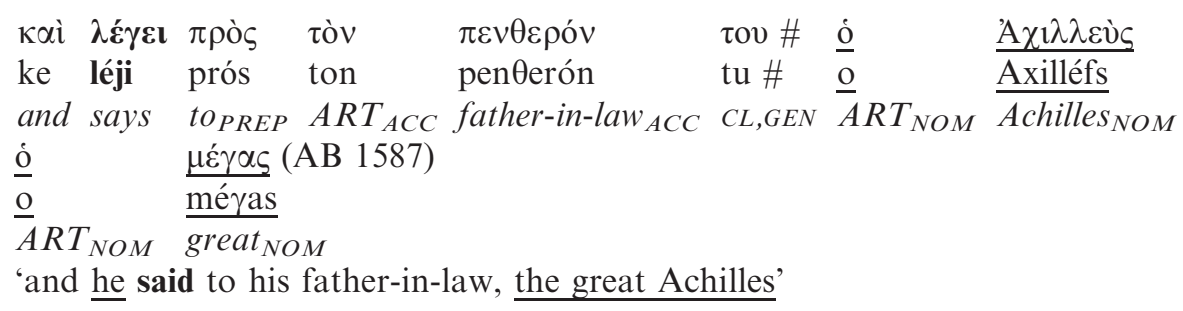

31 Note that parentheticals too are typical of spoken discourse, see Wichmann (2001: 177): 'Parenthetical comments, typically thought of as incidental asides, are a common feature of conversation'.

${ }^{32}$ Moreover, nominative clitic pronouns are only used in a very limited way, e.g. v $\alpha$ os/na tos ('there he is!'). As English is non-pro-drop language, I have underlined the coreferential subject pronoun in my translation. 
(50) $\chi p$

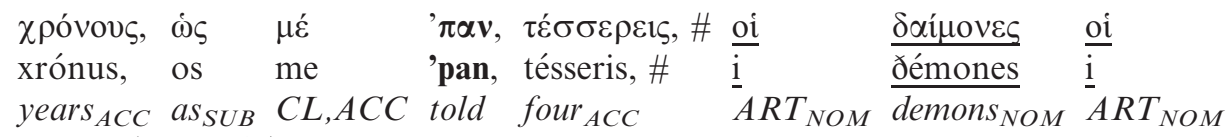
$\underline{\pi \rho \hat{\omega} \tau 01}$ (LR 2747)

próti

first $_{N O M}$

'four years, as they told me, the leading demons'

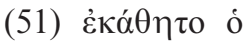

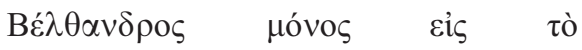

ò $\quad \pi \alpha \lambda \dot{\alpha} \tau \iota$,

eká日ito o

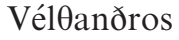

mónos

is to

palátin,

sat $\quad A R T_{N O M}$ Belthandros $_{N O M}$ alone $_{\text {NOM }}$ in $_{\text {PREP }} A R T_{A C C}$ palace $_{A C C}$

'Belthandros sat down on his own in the palace,'

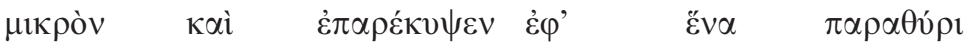

mikrón ke eparékipsen ef' éna para0íri

a while $_{A D V}$ and bended from PREP $_{\text {one }} A C C$ window $_{A C C}$

'he peeped a while from one window'

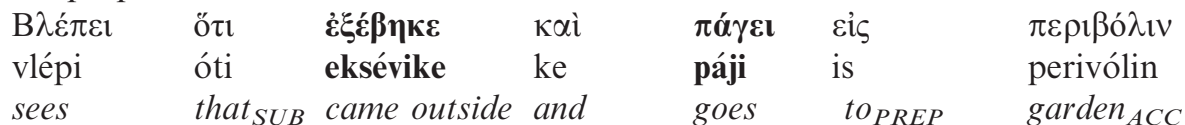

'he saw that she came outside and went to the garden'

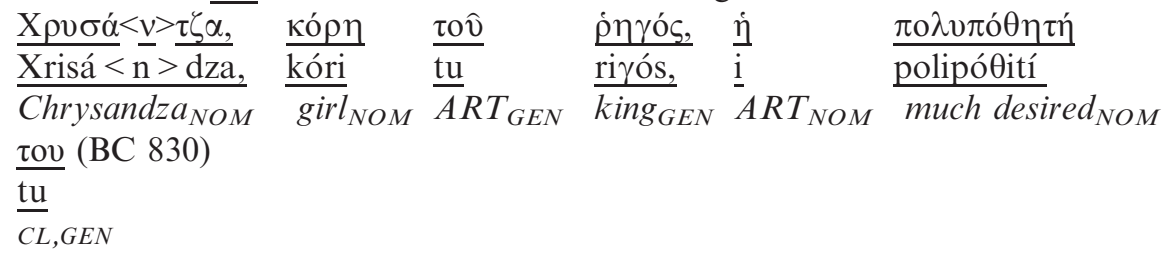

'Chrysandza, girl of the king, his much desired girl'

Rather than purely marking the NPs as topics, these constructions seem to serve a clarifying, even corrective, purpose. As such, they resemble the special instances of corrective topic rightdislocations (cf. section 5.4.2). In the last example, for instance, the verb $\beta \lambda \varepsilon ́ \pi \varepsilon 1 /$ vlépi still has

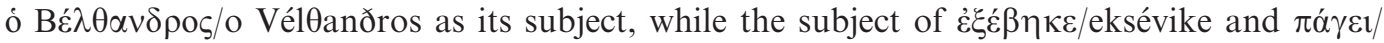

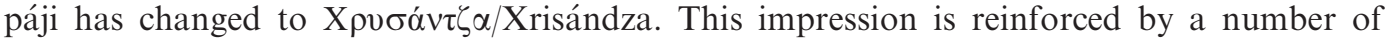
examples in which the verb does not agree in number with the postponed subject. While a multiple subject has been added, the verb stays singular in the following verses:

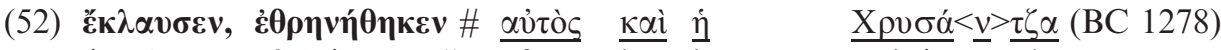

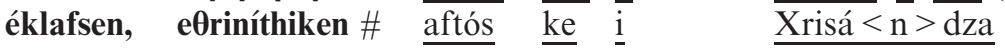
cried lamented $\overline{h e_{N O M}}$ and $A R T_{N O M}$ Chrysandza $a_{N O M}$

'he cried, lamented, he and Chrysandza'

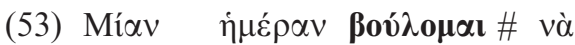

Mían iméran vúlome \# na

One $_{A C C}$ day $_{A C C}$ want

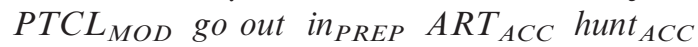

'one day I want to go out hunting,'

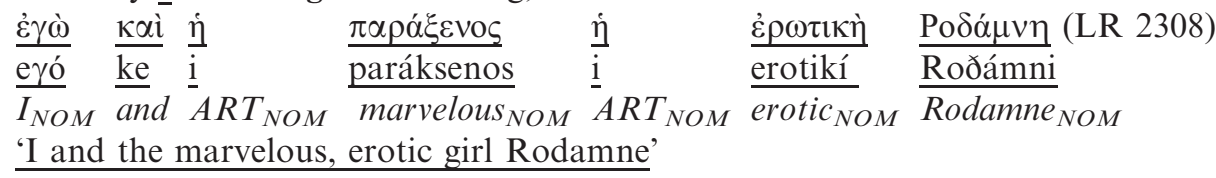


These examples are clearly reminiscent of the examples in which the doubling pronoun has a singular form, although more than one object is added (cf. section 5.4.2).

Whatever the concrete function of the above dislocations is, it might be clear that they constitute even more obvious markers of an adopted oral discourse than the clitic doubling constructions. It is conspicuous that in almost all examples the NP is found to the right of the verb (VO). To be precise, I have found only one example of what can be called a leftdislocated subject:

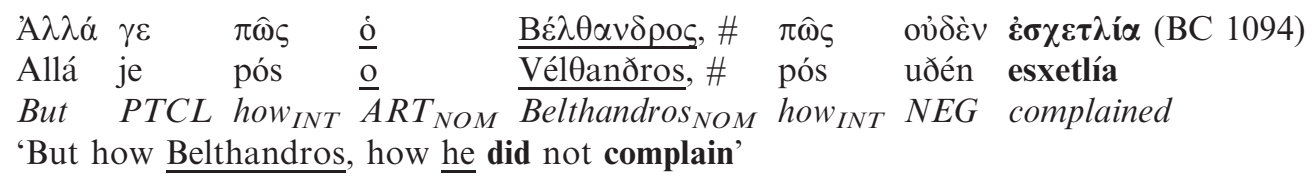

All other examples concern right-dislocations. This observation can be related to the oral discourse of the corpus. Spoken language consists of a linear succession of informational 'chunks', called Idea or Intonation Units by Chafe (1994). Given the instantaneous character of spoken language, mistakes or ambiguities cannot be concealed by a rewrite. Applied to texts, the 'information flow' can be said to proceed from left to right. In view of the assumed oral character of the vernacular poetry, it should come as no surprise that nearly all the above dislocations are right-dislocations: a speaker makes a complete utterance which, however, suddenly seems not entirely straightforward to him (an unspecified subject or an ambiguous pronoun), so that afterwards (i.e. to the right) he/she gives a clarification: the subject is made explicit or the pronoun is repeated by an NP which contains the full load of information.

In this regard, it is interesting to note that in the modern folk-songs the second part of the politikos stichos, i.e. the seven-syllable part after the caesura, commonly clarifies the first

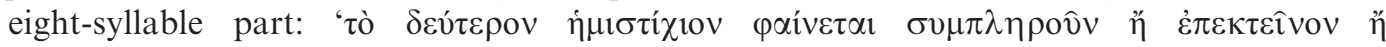

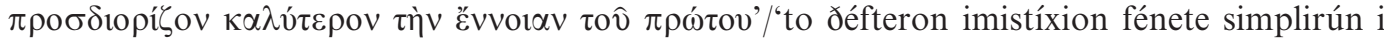
epektínon i prosðiorízon kalíteron tin énnian tu prótu' 'the second hemistich seems to complete or extend or specify in a finer way the idea of the first one' (Kyriakides 1990: 197). This pattern of elaboration actually parallels the above right-dislocations in which the caesura functions as boundary pause for the dislocation. Since the folk-songs contain structures characteristic of colloquial speech, this observation further strengthens the relation of the vernacular poetry to an oral discourse.

\section{Conclusion}

In this paper, clitic doubling in the Medieval Greek vernacular has for the first time been described in detail. On the basis of a representative corpus of fourteenth century romances, I have shown that the co-occurrence of an object NP with a co-referential clitic pronoun indicates topicalized objects in the Medieval Greek vernacular, as in Modern Greek. The main evidence for this assumption is provided by the distribution of clitic pronouns. In Medieval Greek, clitic pronouns can be attracted into preverbal position by ad hoc focalized constituents. The fact that 95.5 per cent of the clitic pronouns doubling a preposed object appears post verbally proves that these doubled NPs must be interpreted as topics. However, the notion 'topic' (as opposed to focus) is often conflated with (referential) 'givenness', since there seems to be a correlation between the two, albeit independent, concepts (Gundel \& Fretheim 2004). Therefore, I have also analysed the doubled NPs according to Chafe's (1994) continuum of activation statuses: no less than 90.5 per cent could be classified as (semi-)active information. 
It is not only the modern function of topic marker that can be adopted; the modern fourpart typology developed by Janse (2008) can also be applied to vernacular Medieval Greek clitic doubling: topicalization, topic left-dislocation, backgrounding, topic right-dislocation, based on word order (OV or VO) and presence/absence of a boundary pause. Although I have been dealing with purely written texts, the latter - prosodic - criterion has caused no difficulties, since vernacular Medieval Greek is inextricably connected with the politikos stichos metre of which both the verse end and the standard caesura can be considered boundary pauses.

Unlike clitic doubling in Modern Greek, the construction is still fairly optional in Medieval Greek and has a rather colloquial character (De Boel 2008). As such, I have considered the frequent occurrence of the doubling construction a piece of further evidence of the oral discourse which the vernacular politikos stichos poetry is acknowledged to adopt. In this regard, I have discussed two structures which are especially related to the special category of corrective topic right-dislocations: dislocated genitives and dislocated subjects, which might lack agreement with the verb. Both constructions definitely constitute further indication of the assumed oral style of the vernacular texts.

As the 'oral discourse' thesis has primarily been defended from a more literary perspective (cf. formulas), it will be revealing to investigate linguistic phenomena typical of spoken language in the texts under consideration. Therefore, I hope that this paper will lead to more studies adopting a linguistic point of departure to substantiate the view that 'the medieval poet, at least the poet of the popular romances, wrote as he spoke' (Crosby 1936: 104).

\section{University of Ghent}

Department of Linguistics

Blandijnberg 2

9000 Gent, Belgium

Email:jorie.soltic@ugent.be

\section{REFERENCES}

Agapitos, Panagiotis, Hult, Karin \& Smith, Ole, 1999. The Byzantine Achilleid. The Naples Version, Vienna: Österreichische Akademie der Wissenschaften.

Alexopoulou, Theodora \& Folli, Raffaella, 2011. 'Indefinite topics and the syntax of nominals in Italian and Greek', WCCFL 28 Proceedings 1, 1-12.

Alexopoulou, Theodora \& Kolliakou, Dimitra, 2002. 'On linkhood, topicalization and clitic left dislocation', Journal of Linguistics 38, 193-245.

Anagnostopoulou, Elena, 1994. Clitic Dependencies in Modern Greek, Ph.D. thesis, University of Salzburg.

Anagnostopoulou, Elena, 1999. 'Conditions on clitic doubling in Greek', in Henk van Riemsdijk (ed.), Clitics in the Languages of Europe, Berlin: Mouton de Gruyter, 761-98.

Apostolopoulos, Photis, 1984. La Langue du Roman Byzantin Callimaque et Chrysorrhoé, Athens: Akadèmia Athènôn.

BeAton, Roderick, 1986. 'The oral traditions of Modern Greece: a survey', Oral Traditions 1, 110-33.

Beaton, Roderick, 1996. The Medieval Greek Romance, 2nd edn, Cambridge: Cambridge University Press.

Brown, Gillian \& Yule, George, 1983. Discourse Analysis, Cambridge: Cambridge University Press.

Chafe, Wallace, 1994. Discourse, Consciousness and Time: The Flow and Displacement of Conscious Experience in Speaking and Writing, Chicago, IL: University of Chicago Press.

Chila-Markopoulou, Despina, 2004. 'Review of Pappas's "Variation and morphosyntactic change in Greek: from clitics to affixes", Journal of Greek Linguistics 5, 199-212.

Condoravdi, Cleo \& Kiparsky, Paul, 2004. 'Clitics and clause structure: the late medieval system', Journal of Greek Linguistics 5, 159-83.

Crosby, Ruth, 1936. 'Oral delivery in the Middle Ages', Speculum 11, 88-110.

Cinque, Guglielmo, 1990. Types of $\bar{A}$-Dependencies, Cambridge, MA: MIT Press.

De Boel, Gunnar, 2008. 'The genesis of clitic doubling from Ancient to Medieval Greek', in Dalina Kallulli \& Liliane Tasmowski (eds.), Clitic Doubling in the Balkan Languages, Philadelphia, PA: John Benjamins, 89-103.

Dik, Helma, 1995. Word Order in Ancient Greek. A Pragmatic Account of Word Order Variation in Herodotus, Amsterdam: J.C. Gieben. 
Dik, Helma, 2007. Word Order in Greek Tragic Dialogue, Oxford: Oxford University Press.

Dik, Simon, 1997. The Theory of Functional Grammar, 2nd edn, Berlin: Mouton de Gruyter.

Dimitriadis, Alexis, 1994. 'Clitics and island-insensitive object-drop', Proceedings of FLSM-5, Urbana-Champaign, IL, Studies in the Linguistic Sciences, 1-54.

Dover, Kenneth, 1960. Greek Word Order, Cambridge: Cambridge University Press.

Egea, José Maria, 1998. Historia extraordinaria de Beltandro y Crisanza, Granada: Athos-Pérgamos.

Eideneier, Hans, 1999. Von Rhapsodie zu Rap: Aspekte der griechischen Sprachgeschichte von Homer bis heute, Tübingen: Narr.

Estigarribia, Bruno, 2006. 'Why clitic doubling? A functional analysis for Rioplatense Spanish', in Timothy Face \& Carole Klee (eds.), Selected Proceedings of the 8th Hispanic Linguistics Symposium, Somerville, MA: Cascadilla Proceedings Project, 123-36.

Ferraresi, Gisella \& Lühr, Rosemarie, 2010. 'The role of information structure in language change: introductory remarks', in Gisella Ferraresi \& Rosemarie Lühr (eds.), Diachronic Studies on Information Structure: Language Acquisition and Change, Berlin: de Gruyter, 1-14.

FÉry, CARoline, 2006. 'The fallacy of invariant phonological correlates of information structural notions', in Caroline Féry, Gisbert Fanselow \& Manfred Krifka (eds.), The Notions of Information Structure, Potzdam \& Berlin: University of Potzdam \& Humboldt University of Berlin, 1-21.

Féry, Caroline, Fanselow, Gisbert \& Krifka, Manfred (eds.), 2006. The Notions of Information Structure, Potzdam \& Berlin: University of Potzdam \& Humboldt University of Berlin.

Geluykens, Ronald, 1992. From Discourse Process to Grammatical Construction: On Left-Dislocation in English, Amsterdam: John Benjamins.

Givon, Talmy, 2001. Syntax: An Introduction, vol. 1, Amsterdam: John Benjamins.

Guentchéva, ZlatKa, 2008. 'Object clitic doubling constructions and topicality in Bulgarian', in Dalina Kallulli \& Liliane Tasmowski (eds.), Clitic Doubling in the Balkan Languages, Philadelphia, PA: John Benjamins, $203-23$.

Gundel, Jeanette \& Fretheim, Thorstein, 2004. 'Topic and focus', in Laurence Horn \& Gregory Ward (eds.), The Handbook of Pragmatics, Oxford: Blackwell, 175-96.

Gundel, Jeanette, Hedberg, Nancy \& Zacharski, Ron, 1993. 'Cognitive status and the form of referring expressions in discourse', Language 69, 274-307.

Haberland, Hartmut \& Van der Auwera, Johan, 1987. 'Doubling and resumption in Modern Greek', Studies in Greek Linguistics. Proceedings of the 8th annual meeting of the Department of Linguistics, Faculty of Philosophy, Aristotelian University of Thessaloniki, 27-29 April 1987 (A Festschrift for John Chadwick), 323-34.

Heim, Irene, 1982. The Semantics of Definite and Indefinite Noun Phrases, Ph.D. thesis, University of Massachusetts, Amherst.

Hendriks, Herman \& Dekker, Paul, 1995. 'Links without locations' in Paul Dekker \& Martin Stokhof (eds.), Proceedings of the Tenth Amsterdam Colloquium, ILLC: University of Amsterdam, 339-58

Hinterberger, Martin, 1993. 'Sprachliche Variationsformen in volkssprachlichen metrischen Werken der spätbyzantinischen und frühneugriechischen Zeit', in Nikolaos Panayotakis (ed.), Origini della Literatura Neogreca, vol. 1, Venice: Instituto Ellenico di Studi Bizantini e Postbizantini di Venezia, 158-68.

Holton, David, Mackridge, Peter \& Philippaki-Warburton, Irene, 2004. Greek. An Essential Grammar of the Modern Language, London: Routledge.

Horrocks, Geoffrey, 2010. Greek: A History of the Language and its Speakers, 2nd edn, London: Longman.

Iatridou, Sabine, 1995. 'Clitics and island effects', Penn Working Papers in Linguistics 2, 11-31.

JAnse, Mark, 2008. 'Clitic doubling from Ancient to Asia Minor Greek', in Dalina Kallulli \& Liliane Tasmowski (eds.), Clitic Doubling in the Balkan Languages, Philadelphia, PA: John Benjamins, 165-202.

Jeffreys, Michael, 1973. 'Formulas in the Chronicle of the Morea', Dumbarton Oak Papers 27, 163-95.

Kallulli, Dalina, 2008. 'Clitic doubling, agreement and information structure', in Dalina Kallulli \& Liliane Tasmowski (eds.), Clitic Doubling in the Balkan Languages, Philadelphia, PA: John Benjamins, $227-56$.

Krapova, Iliyana \& Cinque, Guglielmo, 2008. 'Clitic reduplication constructions in Bulgarian' in Dalina Kallulli \& Liliane Tasmowski (eds.), Clitic Doubling in the Balkan Languages, Philadelphia, PA: John Benjamins, $257-86$.

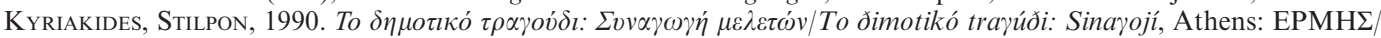
ERMIS.

Lauxtermann, Marc, 1999. The Spring of Rhythm: An Essay on the Political Verse and Other Byzantine Metres, Vienna: Verlag der Österreichischen Akademie der Wissenschaften.

Lendari, Tina, 2007. Livistros and Rodamne. The Vatican Version. Critical Edition with Introduction, Commentary and Index-Glossary, Athens: MIET.

Mackridge, Peter, 1990. 'Orality in Medieval and Modern Greek poetry: introduction', Byzantine and Modern Greek Studies 14, 123-28.

Mackridge, Peter, 1993. 'An editorial problem in Medieval Greek texts. The position of the object clitic pronoun in the Escorial Digenes Akrites', in N. Panayotakis (ed.), Origini della Literatura Neogreca, vol. 1, Venice: Instituto Ellenico di Studi Bizantini e Postbizantini di Venezia, 325-42.

Mackridge, Peter, 1995. 'On the placement of the weak personal pronoun in Medieval Greek vernacular', Studies in Greek Linguistics 15, 906-29.

Mackridge, Peter, 2000. 'The position of the weak object pronoun in Medieval and Modern Greek', Jazyk i rečevaja dejatel'nost' 3, 133-51. 
Manolessou, Io \& Stamatis, Beis, 2006. 'Syntactic isoglosses in Modern Greek dialects: the case of the indirect object' in Mark Janse, Brian Joseph \& Angela Ralli (eds.), Proceedings of the 2nd International Conference on Modern Greek Dialects and Linguistic Theory, Patras: University of Patras, 220-35.

Pappas, Panayiotis, 2004. Variation and Morphosyntactic Change in Greek. From Clitics to Affixes, Basingstoke: Palgrave MacMillan.

Philippaki-Warburton, Irene, 1975. 'The passive in English and Greek', Foundations of Language 13, 563-78.

Philippaki-Warburton, Irene, 1977. "Modern Greek clitic pronouns and the "surface syntax constraints" hypothesis', Journal of Linguistics 13, 259-81.

Philippaki-Warburton, Irene, 1985. 'Word order in Modern Greek', Transactions of the Philological Society 83, 11343.

Philippaki-Warburton, Irene, 1994. 'Verb movement and clitics in Modern Greek', in Irene Philippaki-Warburton, Katerina Nicolaidis \& Maria Sifianou (eds.), Themes in Greek Linguistics, vol. 1, Amsterdam: Benjamins, 53-60.

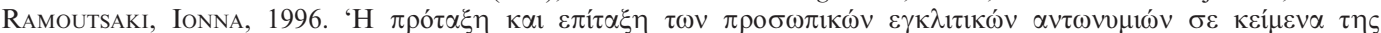

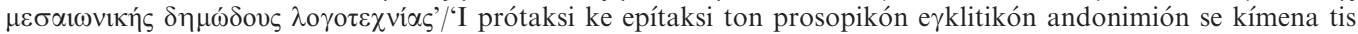

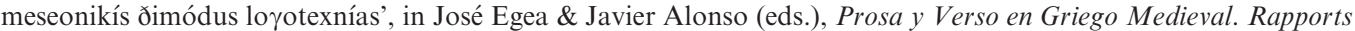
of the International Congress 'Neograeca Medii Aevi III' Vitoria 1994, Amsterdam: Hakkert, 317-20.

Revithiadou, Anthi \& Spyropulos, Vassilios, 2006. A Typology of Greek Clitics with Special Reference to their Diachronic Environment, Rhodes: University of the Aegean.

Revithiadou, Anthi \& Spyropulos, Vassilios, 2008. 'Greek object clitic pronouns: a typological survey of their grammatical properties', Language Typology and Universals 61, 39-53.

Rosenqvist, Jan Olof, 2007. Die byzantinische Literatur. Vom 6. Jahrhundert bis zum Fall Konstantinopels 1453, Berlin; New York: Walter de Gruyter.

Seidl, Amanda \& Dimitriadis, Alexis, 1997. 'The discourse function of object marking in Swahili', CLS (Chicago Linguistic Society) 33: The Main Session, 373-89.

Shawcross, Teresa, 2005. 'Oral residue and narrative structure in the Chronicle of Morea', Byzantion 75, 310-33.

Sifakis, Gregory, 2001. 'Looking for the tracks of oral tradition in Medieval and Early Modern Greek poetic works', Journal of the Hellenic Diaspora 27, 61-86.

Soltic, Jorie, 2012. 'Distribution of the object clitic pronouns in the Grottaferrata manuscript of the Digenis Akritis', Byzantine and Modern Greek Studies 36, 178-97.

Thoma, Chrystalla, 2007. 'Distribution and function of clitic object pronouns in popular 16th-18th century Greek narratives. A synchronic and diachronic perspective', in Jochen Rehbein, Christiane Hohenstein \& Lukas Pietsch (eds.), Connectivity in Grammar and Discourse, Amsterdam: John Benjamins, 139-63.

Tomic, Olga, 2006. 'Clitic clusters and clitic doubling, Balkan Sprachbund and morpho-syntactic features', Studies in Natural Language and Linguistic Theory 67, 239-331.

Trypanis, Constantine, 1963. 'Byzantine oral poetry', Byzantinische Zeitschrift 56, 1-3.

VAllduví, Enric, 1992. The Informational Component, Ph.D. thesis, New York: Garland.

Vejleskov, Peter, 2005. 'The position of the weak object pronoun in the Greek Portulans and in the Chronicle of the Turkish Sultans', in Elizabeth \& Michael Jeffreys (eds.), Approaches to Texts in Early Modern Greek (Neograeca Medii Aevi V), Oxford: University of Oxford, 197-209.

Wichmann, Anne, 2001. 'Spoken parentheticals', in Karin Aijmer (ed.), A Wealth of English (Studies in Honour of Göran Kjellmer), Gothenburg: Acta Universitatis Gothoburgensis, 177-93.

Ziv, YAel, 1994. 'Left and right dislocations: discourse functions and anaphora', Journal of Pragmatics 22, 629-45. 